\title{
Temperature thresholds for chlorine activation and ozone loss in the polar stratosphere
}

\author{
K. Drdla ${ }^{1}$ and R. Müller ${ }^{2}$ \\ ${ }^{1}$ NASA Ames Research Center, Moffett Field, CA, USA \\ ${ }^{2}$ Institute of Energy and Climate Research (IEK-7), Forschungszentrum Jülich, 52425 Jülich, Germany \\ Correspondence to: R. Müller (ro.mueller@fz-juelich.de)
}

Received: 23 March 2012 - Accepted: 19 June 2012 - Published: 13 July 2012

\begin{abstract}
Low stratospheric temperatures are known to be responsible for heterogeneous chlorine activation that leads to polar ozone depletion. Here, we discuss the temperature threshold below which substantial chlorine activation occurs. We suggest that the onset of chlorine activation is dominated by reactions on cold binary aerosol particles, without the formation of polar stratospheric clouds (PSCs), i.e. without any significant uptake of $\mathrm{HNO}_{3}$ from the gas phase. Using reaction rates on cold binary aerosol in a model of stratospheric chemistry, a chlorine activation threshold temperature, $T_{\mathrm{ACL}}$, is derived. At typical stratospheric conditions, $T_{\mathrm{ACL}}$ is similar in value to $T_{\mathrm{NAT}}$ (within $1-2 \mathrm{~K}$ ), the highest temperature at which nitric acid trihydrate (NAT) can exist. $T_{\mathrm{NAT}}$ is still in use to parameterise the threshold temperature for the onset of chlorine activation. However, perturbations can cause $T_{\mathrm{ACL}}$ to differ from $T_{\mathrm{NAT}}: T_{\mathrm{ACL}}$ is dependent upon $\mathrm{H}_{2} \mathrm{O}$ and potential temperature, but unlike $T_{\mathrm{NAT}}$ is not dependent upon $\mathrm{HNO}_{3}$. Furthermore, in contrast to $T_{\mathrm{NAT}}, T_{\mathrm{ACL}}$ is dependent upon the stratospheric sulfate aerosol loading and thus provides a means to estimate the impact on polar ozone of strong volcanic eruptions and some geo-engineering options, which are discussed. A parameterisation of $T_{\mathrm{ACL}}$ is provided here, allowing it to be calculated for low solar elevation (or high solar zenith angle) over a comprehensive range of stratospheric conditions. Considering $T_{\mathrm{ACL}}$ as a proxy for chlorine activation cannot replace a detailed model calculation, and polar ozone loss is influenced by other factors apart from the initial chlorine activation. However, $T_{\mathrm{ACL}}$ provides a more accurate description of the temperature conditions necessary for chlorine activation and ozone loss in the polar stratosphere than $T_{\mathrm{NAT}}$.
\end{abstract}

Keywords. Atmospheric composition and structure (Middle atmosphere - composition and chemistry)

\section{Introduction}

For more than two decades, most of the stratospheric ozone over Antarctica has disappeared each spring in a phenomenon commonly known as the "ozone hole" (Farman et al., 1985; Stolarski et al., 1986; Jones and Shanklin, 1995). Similar but more variable and less severe ozone loss has occurred in the Arctic (e.g., Hofmann et al., 1989; Müller et al., 1996; Manney et al., 2003; Rex et al., 2004; Tilmes et al., 2004). The strongest ozone loss so far in the Arctic was observed in early spring 2011 (Manney et al., 2011). It is well established that polar ozone is lost through rapid, gas phase catalytic cycles involving chlorine atoms (McElroy et al., 1986; Molina and Molina, 1987; Solomon, 1999), which are primarily derived from man-made chemicals such as chlorofluorocarbons (CFCs).

Although chlorine is present throughout the stratosphere, it is usually bound in relatively inert "reservoir" species, in particular $\mathrm{HCl}$ and $\mathrm{ClONO}_{2}$, so that the severe polar ozone loss cannot be explained solely on the basis of gas phase chemistry. As early as 1986, heterogeneous reactions on the surfaces of polar stratospheric clouds (PSCs) were suggested to be an important element of polar ozone chemistry (McElroy et al., 1986; Solomon et al., 1986). Of particular importance for liberating the ozone-destroying potential of chlorine is the reaction between $\mathrm{HCl}$ and $\mathrm{ClONO}_{2}$ (Reaction R1), which leads to a conversion of the chlorine bound in reservoir species to active, ozone-destroying, chlorine compounds (Solomon et al., 1986).

Heterogeneous reactions have an influence on the extent of chlorine activation and polar ozone loss during three phases in polar winter and spring: first, the initial rapid activation, when temperatures in polar winter first fall below the threshold that allows heterogeneous chlorine activation to be 
effective; second, the slower activation of the $\mathrm{HCl}$ that remains after the initial activation (e.g., Crutzen et al., 1992; Müller et al., 1994; Portmann et al., 1996); and, finally, the period in late winter and spring when heterogeneous reactions compete with rapid gas phase deactivation reactions for the maintenance of high levels of active chlorine (e.g., Portmann et al., 1996; Grooß et al., 2011).

This paper revisits the processes controlling the onset of heterogeneous chlorine activation, when air masses cool from temperatures above $\sim 196 \mathrm{~K}$, where heterogeneous chlorine activation is negligible, to lower temperatures where heterogeneous chlorine activation is rapid. These processes are important for reliable assessments of future polar ozone loss. In the future, the pattern of chlorine activation might be altered through climate change (IPCC/TEAP, 2005; WMO, 2007, 2011), strong volcanic eruptions, or, possibly, through "geo-engineering", i.e., an artificial enhancement of the stratospheric sulfate layer (Crutzen, 2006; Tilmes et al., 2008a; Rasch et al., 2008).

The most important heterogeneous reactions for chlorine activation are

$$
\begin{aligned}
& \mathrm{ClONO}_{2}+\mathrm{HCl} \rightarrow \mathrm{Cl}_{2}+\mathrm{HNO}_{3} \\
& \mathrm{ClONO}_{2}+\mathrm{H}_{2} \mathrm{O} \rightarrow \mathrm{HOCl}+\mathrm{HNO}_{3} \\
& \mathrm{HCl}+\mathrm{HOCl} \rightarrow \mathrm{Cl}_{2}+\mathrm{H}_{2} \mathrm{O}
\end{aligned}
$$

In each reaction, reservoir species $\left(\mathrm{ClONO}_{2}, \mathrm{HCl}\right)$ are converted into photolabile species $\left(\mathrm{Cl}_{2}, \mathrm{HOCl}\right)$ that photolyse readily in springtime, initiating gas phase ozone destruction. Reactions (R1)-(R3) are very slow in the gas phase, but they are efficient both in the liquid phase and on solid particle surfaces at low temperatures. The efficiency of each reaction varies depending upon the type of particle and the prevailing temperature (Tolbert et al., 1988; Ravishankara and Hanson, 1996; Carslaw and Peter, 1997; Peter, 1997; Solomon, 1999; Lowe and MacKenzie, 2008; Sander et al., 2011; Peter and Grooß, 2012). Particles of different physical states and compositions may coexist in the same stratospheric air parcel (e.g., Solomon, 1999; Blum et al., 2005; Pitts et al., 2009, 2011; Khosrawi et al., 2011).

Sulfate aerosol particles, composed of binary $\mathrm{H}_{2} \mathrm{SO}_{4} / \mathrm{H}_{2} \mathrm{O}$ solutions, are ubiquitous in the stratosphere. More limited in extent are PSCs, which only form at the low temperatures of polar winter. The most prevalent PSC types are composed of $\mathrm{HNO}_{3}$, either the more stable solid-phase compound nitric acid trihydrate (NAT), or liquid supercooled ternary solutions (STS) of $\mathrm{HNO}_{3} / \mathrm{H}_{2} \mathrm{SO}_{4} / \mathrm{H}_{2} \mathrm{O}$. The transition from binary $\mathrm{H}_{2} \mathrm{SO}_{4} / \mathrm{H}_{2} \mathrm{O}$ particles to STS particles is continuous. However, the uptake of $\mathrm{HNO}_{3}$ and the resulting growth in particle volume increases rapidly below $\sim 193 \mathrm{~K}$ at typical stratospheric conditions (Carslaw et al., 1994; Peter, 1997; Lowe and MacKenzie, 2008; Peter and Grooß, 2012). Water ice PSCs will form at temperatures below the ice frost point. Multiple factors, in particular temperature, determine the mixture of different PSC particles present at any location.
The efficiency of heterogeneous reactions on a particular particle type is described by the (dimensionless) reactive uptake coefficient $\gamma$ (also called sticking coefficient). The reactivity on NAT particles is poorly determined from laboratory measurements (Carslaw and Peter, 1997; WMO, 1999; Peter and Grooß, 2012), with the temperature-dependent $\gamma$-values based on the measurements by Hanson and Ravishankara (1993) being substantially greater than those based on Abbatt and Molina (1992). There is also some uncertainty regarding the reactivity on liquid particles, but the difference between the different parameterisations is much less than in the case of NAT (see Fig. 6 in Shi et al., 2001).

The onset of chlorine activation is determined by the particles which, upon cooling of the polar stratosphere, first provide surfaces for efficient heterogeneous reactions. Because the formation of solid NAT PSCs is difficult under stratospheric conditions and therefore requires substantial supercooling, liquid-phase particles will likely control the onset of chlorine activation (Solomon, 1999; Peter and Grooß, 2012).

PSCs frequently contain liquid-phase STS particles (e.g., Carslaw et al., 1997a; Peter, 1997; Solomon, 1999; Pitts et al., 2009), and laboratory studies have revealed that chemistry on liquid PSCs is efficient (e.g., Tolbert et al., 1988; Hanson et al., 1994; Shi et al., 2001). Studies have increasingly emphasised the importance of STS PSCs for chlorine activation (e.g., Hanson et al., 1994; Ravishankara and Hanson, 1996; Kawa et al., 1997; Solomon, 1999; Engel et al., 2000; Hanisco et al., 2002). Further, binary $\mathrm{H}_{2} \mathrm{SO}_{4} / \mathrm{H}_{2} \mathrm{O}$ aerosol particles have been discussed for many years as a potentially important contributor to chlorine chemistry and polar ozone loss (Hofmann and Solomon, 1989; Wolff and Mulvaney, 1991; Turco and Hamill, 1992; Hofmann and Oltmans, 1993; Cox et al., 1994; Hanson et al., 1994; Portmann et al., 1996).

Uptake coefficients for Reactions (R1)-(R3) for liquid (cold binary and STS) and NAT particles are shown in Fig. 1. The $\gamma$-values for liquid particles (green lines) are deduced from the parameterisation by Shi et al. (2001) as recommended by the NASA/JPL panel for evaluation kinetic and photochemical data (Sander et al., 2011). For NAT, two options for $\gamma$ are shown: the recommended values (Sander et al., 2011), i.e., constant $\gamma$-values (red lines, "NAT, Original") and temperature-dependent $\gamma$-values from Carslaw and Peter (1997) based on the laboratory measurements by Abbatt and Molina (1992) ("NAT, New $\gamma$ ", magenta line).

In the late 1980s and early 1990s, as an explanation for the Antarctic ozone hole and polar ozone loss, the picture emerged that chlorine activation occurs on the surfaces of solid PSCs consisting of either NAT or ice (e.g., Salawitch et al., 1988; Henderson et al., 1990). Models designed to explain observations of a perturbed polar chlorine chemistry were based on the assumption that chlorine activation occurs on NAT and ice surfaces (e.g., Jones et al., 1990a; Crutzen et al., 1992; Prather, 1992; Müller et al., 1994; Chipperfield et al., 1994; Kettleborough et al., 1994). Furthermore, 


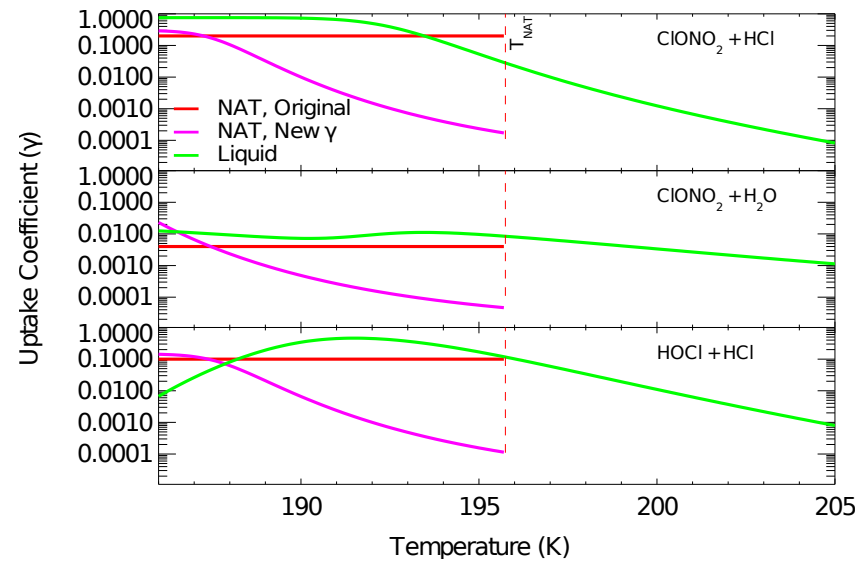

Fig. 1. Reactive uptake coefficients $(\gamma)$ used in this work as a function of temperature for Reactions (R1)-(R3). Assumed molar mixing ratios of traces species are $1 \mathrm{ppbv} \mathrm{ClONO}_{2}, 2$ ppbv $\mathrm{HCl}, 5 \mathrm{ppmv}$ $\mathrm{H}_{2} \mathrm{O}, 0.15 \mathrm{ppbv} \mathrm{H}_{2} \mathrm{SO}_{4}$. Calculations are for $50 \mathrm{hPa}$. For the reactive uptake on liquid particles, the parameterisation reported by Shi et al. (2001) is employed (green lines), as recommended (Sander et al., 2011). For NAT particles, the (constant) recommended reactive uptake coefficients (Sander et al., 2011) are shown (NAT, Original; red lines) as well as the temperature-dependent $\gamma$-values from Carslaw and Peter (1997) based on the laboratory measurements by Abbatt and Molina (1992) (NAT, New $\gamma$; magenta line).

observations indicated that the onset of chlorine activation occurs at $195 \mathrm{~K}$ (Toohey et al., 1993; Webster et al., 1993; Santee et al., 1997; Kühl et al., 2004), coinciding with $T_{\mathrm{NAT}}$, the temperature threshold below which NAT can exist. Although it has been stated for more than a decade that polar chlorine activation is caused to a large extent by heterogeneous reactions on liquid-phase particles (e.g., Solomon, 1999 ), $T_{\mathrm{NAT}}$ (or, alternatively, $195 \mathrm{~K}$ ) is still being used as a first-order approximation to parameterise the onset of heterogeneous chlorine activation in models (Geer et al., 2006; Kiesewetter et al., 2010; Eyring et al., 2010; Morgenstern et al., 2010).

Furthermore, measurements have shown that the total volume of air exposed to temperatures below $T_{\mathrm{NAT}}$ (labelled $\left.V_{\text {PSC }}\right)$ is quantitatively related to springtime ozone loss (Rex et al., 2004, 2006; Tilmes et al., 2004). This relationship has been used to estimate future ozone loss (Knudsen et al., 2004) and to evaluate model performance (Chipperfield et al., 2005; Douglass et al., 2006). However, variability in $V_{\text {PSC }}$ values from one study to another has raised questions about the definitions of $T_{\mathrm{NAT}}$ and $V_{\mathrm{PSC}}$ (Chipperfield et al., 2005). Answering these questions requires an understanding of the physical and chemical processes linking $T_{\mathrm{NAT}}$ to chlorine activation and ozone loss.

Here, we will examine the factors controlling the onset of chlorine activation, and by implication ozone loss, in polar winter. We suggest that heterogeneous reactions on liquid, cold binary aerosols are effective at temperatures near $195 \mathrm{~K}$, without PSC formation, i.e. without a significant depletion of $\mathrm{HNO}_{3}$ in the gas phase. Using liquid reactivities, a temperature threshold for chlorine activation, $T_{\mathrm{ACL}}$, is derived, and its behaviour under varying stratospheric conditions is described. Inaccuracies introduced by using $T_{\mathrm{NAT}}$ as a proxy for the chlorine activation threshold temperature are explored, suggesting that $T_{\mathrm{ACL}}$ will provide a more accurate description than $T_{\mathrm{NAT}}$ of the onset of polar chlorine activation and ozone loss.

Some years ago, the concept of $T_{\mathrm{ACL}}$ (including the parametrisation in Eq. 2) was presented at conferences (Drdla, 2005, 2006). Based on these presentations, $T_{\mathrm{ACL}}$ as a threshold temperature for polar chlorine activation has been employed recently to study the effect of a possible future hydrogen economy on polar ozone loss (Feck et al., 2008), to evaluate the performance of chemistry climate models (Tilmes et al., 2007), and to estimate the possible effect of a mitigation of climate change by the artificial injection of sulfur into the stratosphere (Crutzen, 2006; Rasch et al., 2008) on polar ozone loss (Tilmes et al., 2008a, 2009). A preliminary account of the findings reported here was given by Drdla and Müller (2010).

\section{Heterogeneous chemistry on nitric acid trihydrate}

Because NAT is the most stable composition for condensed phase, crystalline $\mathrm{HNO}_{3}$ under stratospheric conditions, $T_{\mathrm{NAT}}$ is the highest temperature at which polar stratospheric clouds containing crystalline particles containing $\mathrm{HNO}_{3}$ can exist. Based on a formula derived from laboratory measurements (Hanson and Mauersberger, 1988; Worsnop et al., $1993), T_{\mathrm{NAT}}$ can be calculated in a simple way, as a function of atmospheric pressure and of $\mathrm{H}_{2} \mathrm{O}$ and $\mathrm{HNO}_{3}$ partial pressures. Comparison of $T_{\mathrm{NAT}}$ with temperatures of meteorological analyses allows an assessment of where polar stratospheric NAT clouds can potentially exist.

The temperature dependence of chlorine activation resulting from the assumption that chlorine activation occurs at $T_{\text {NAT }}$ is illustrated in Fig. 2 where the line labelled "NAT, Original" provides the chlorine reactivity on NAT particles as a function of temperature. The rate (in units of $\mathrm{s}^{-1}$ ) of an individual heterogeneous reaction on a given particle type is determined from

$k=\frac{1}{4} \gamma \cdot \mathrm{SA} \cdot v$

(Hofmann and Solomon, 1989; Brasseur and Solomon, 2005), where $\gamma$ is the reactive uptake coefficient (Fig. 1) for the reaction on the particle type, SA is the total surface area density of the particle type, and $v$ is the mean molecular velocity of the gas phase reactant.

A model (Drdla et al., 2002; Drdla and Schoeberl, 2002) has been used to calculate surface areas and reaction probabilities as a function of temperature for all relevant particle types. Assumed chlorine levels are $1 \mathrm{ppbv}$ for $\mathrm{ClONO}_{2}$ 


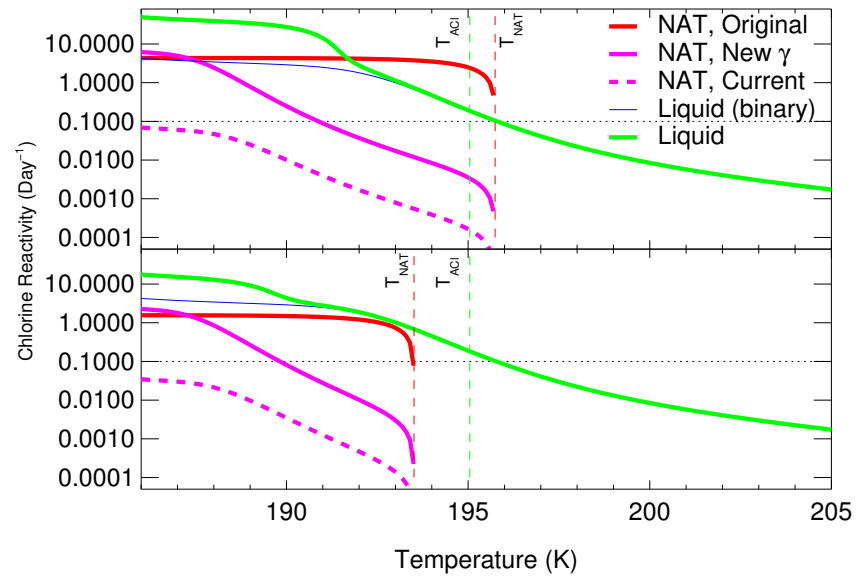

Fig. 2. Chlorine reactivity from heterogeneous reactions as a function of temperature, for several particulate compositions and reaction probabilities. Calculations are for $50 \mathrm{hPa}$. (Top panel) Typical stratospheric conditions (10 ppbv $\mathrm{HNO}_{3}, 5 \mathrm{ppmv} \mathrm{H}_{2} \mathrm{O}$ ). (Bottom panel) Denitrified conditions ( 2 ppbv $\mathrm{HNO}_{3}$ ). Chlorine reactivity is calculated by adding up the loss rates of both $\mathrm{ClONO}_{2}$ and $\mathrm{HCl}$ due to Reactions (R1)-(R3). The resulting total is divided by the sum of the concentration of $\mathrm{ClONO}_{2}$ and $\mathrm{HCl}$. (Assumed chlorine levels are $1 \mathrm{ppbv}$ for $\mathrm{ClONO}_{2}$ and $2 \mathrm{ppbv}$ for $\mathrm{HCl}$.) For the "NAT, Original" case, NAT is assumed to form immediately at $T_{\text {NAT }}$. The surface area density is calculated assuming a NAT particle concentration of $1 \mathrm{~cm}^{-3}$ and that all excess $\mathrm{HNO}_{3}$ condenses (i.e., NAT is at equilibrium). The reaction probabilities ( $\gamma$-values) on NAT are assumed to be constant, specifically 0.2 for (Reaction R1), 0.004 for (Reaction R2), and 0.1 for (Reaction R3) (Sander et al., 2006, 2011, Table 5-2). "NAT, Current" demonstrates the decrease in NAT reactivity relative to "NAT, Original" caused by updated assumptions about surface area and reaction probability (see text for details). The "NAT, Current" case assumes that the NAT surface area density is $0.1 \mu \mathrm{m}^{2} \mathrm{~cm}^{-3}$. This surface area is consistent with a NAT particle concentration of $10^{-4} \mathrm{~cm}^{-3}$ after five days of continuous growth (see Fig. 3 below). The NAT reaction probabilities are the same as in the "NAT, New $\gamma$ " case. "NAT, New $\gamma$ " combines the high surface areas from "NAT, Original" with the updated reaction probabilities (from Carslaw and Peter, 1997, lower limit scheme based on the measurements by Abbatt and Molina, 1992) of "NAT Current". Each NAT case shows the reactivity due to NAT particles alone. "Liquid" shows the reactivity on liquid sulfate aerosols (assuming 0.15 ppbv $\mathrm{H}_{2} \mathrm{SO}_{4}$ ) incorporating $\mathrm{HNO}_{3}$ uptake to form STS. "Liquid (binary)" shows the reactivity on liquid aerosols for binary $\mathrm{H}_{2} \mathrm{SO}_{4} / \mathrm{H}_{2} \mathrm{O}$ solutions, i.e. without $\mathrm{HNO}_{3}$ uptake (Shi et al., 2001; Sander et al., 2011).

and 2 ppbv for $\mathrm{HCl}$ (e.g., Wilmouth et al., 2006). For the "NAT, Original" reactivity, NAT is assumed to be in equilibrium with the gas phase and is assumed to form at $T_{\mathrm{NAT}}$, and the surface area is calculated assuming a NAT particle concentration of $1 \mathrm{~cm}^{-3}$. This yields a large surface area density $\left(\sim 7 \mu \mathrm{m}^{2} \mathrm{~cm}^{-3}\right)$. The reaction probabilities on NAT are assumed to be constant, specifically 0.2 for (Reaction R1), 0.004 for (Reaction R2), and 0.1 for (Reaction R3), following the current recommendation (Sander et al., 2006, 2011,
Table 5-2). The resultant loss rates of both $\mathrm{ClONO}_{2}$ and $\mathrm{HCl}$ due to Reactions (R1)-(R3) were added up and divided by the sum of the concentration of $\mathrm{ClONO}_{2}$ and $\mathrm{HCl}$ to provide the normalised chlorine reactivity shown in Fig. 2.

For the "NAT, Original" calculation, a step increase in reactivity occurs at $T_{\mathrm{NAT}}$. Above $T_{\mathrm{NAT}}$ there is no chlorine activation, but $1 \mathrm{~K}$ below $T_{\mathrm{NAT}}$ the initial activation step (i.e., the depletion of $\mathrm{ClONO}_{2}$ ) takes only one day. However, the "NAT, Original" reactivity is contingent upon three distinct assumptions, all of which must be satisfied for $T_{\text {NAT }}$ to provide a reliable indicator of chlorine activation: (1) NAT nucleates promptly once temperature drops below $T_{\mathrm{NAT}}$; (2) NAT nucleates in a large fraction of the pre-existing aerosol particles resulting in large number densities and thus in large surface area densities of NAT particles; and (3) chlorine activation on NAT is rapid at temperatures near $T_{\mathrm{NAT}}$.

The last assumption, that reaction probabilities on NAT are fast near $T_{\mathrm{NAT}}$, is true when the reaction probabilities are assumed to be constant instead of temperature-dependent. Laboratory measurements (Abbatt and Molina, 1992; Hanson and Ravishankara, 1993) have shown that on NAT all three Reactions (R1)-(R3) are sensitive to the relative humidity, which increases rapidly with decreasing temperature. However, Carslaw and Peter (1997) found that the laboratory measurements by Abbatt and Molina (1992) and by Hanson and Ravishankara (1993) led to very different reactive uptake coefficients for Reaction (R1) (up to factors of 50 to 100, Carslaw and Peter, 1997; WMO, 1999). Following Carslaw et al. (1997b), we suggest that two schemes should be considered for Reactions (R1)-(R3) on NAT particles: one based on the measurements by Hanson and Ravishankara (1993) as an upper limit, and one based on an extrapolation of the measurements by Abbatt and Molina (1992) as the lower limit. Incorporating the humidity dependence of NAT reactivity (Carslaw and Peter, 1997), adopting the lower limit scheme provided by Carslaw and Peter (1997) (based on the measurements by Abbatt and Molina, 1992), and assuming the same large NAT surface areas as "NAT, Original" decreases chlorine reactivities at $T_{\mathrm{NAT}}$ by three orders of magnitude ("NAT, New $\gamma$ "). The reactivity only exceeds 0.1 day $^{-1}$ at $5 \mathrm{~K}$ or more below $T_{\mathrm{NAT}}$ and cooling to the ice frost point is necessary to approach the "NAT, Original" values (Fig. 2).

A similar figure to Fig. 2 showing heterogeneous chlorine reactivity was published by Dameris et al. (2007), who used the upper limit scheme based on the measurements by Hanson and Ravishankara (1993) for the NAT reactivity and obtained the same basic result, namely that the time scale for heterogeneous chlorine activation of a typical NAT cloud is much longer than that on liquid aerosol particles.

Furthermore, PSCs are often not present at temperatures below $T_{\text {NAT }}$ (Schlager et al., 1990; Dye et al., 1990; Pitts et al., 2007, 2009; WMO, 2011; Lambert et al., 2012) and the PSCs that do form are frequently liquid-phase STS PSCs or mixtures of NAT and STS particles instead of pure NAT (Carslaw et al., 1997a; Peter, 1997; Solomon, 1999; Blum 


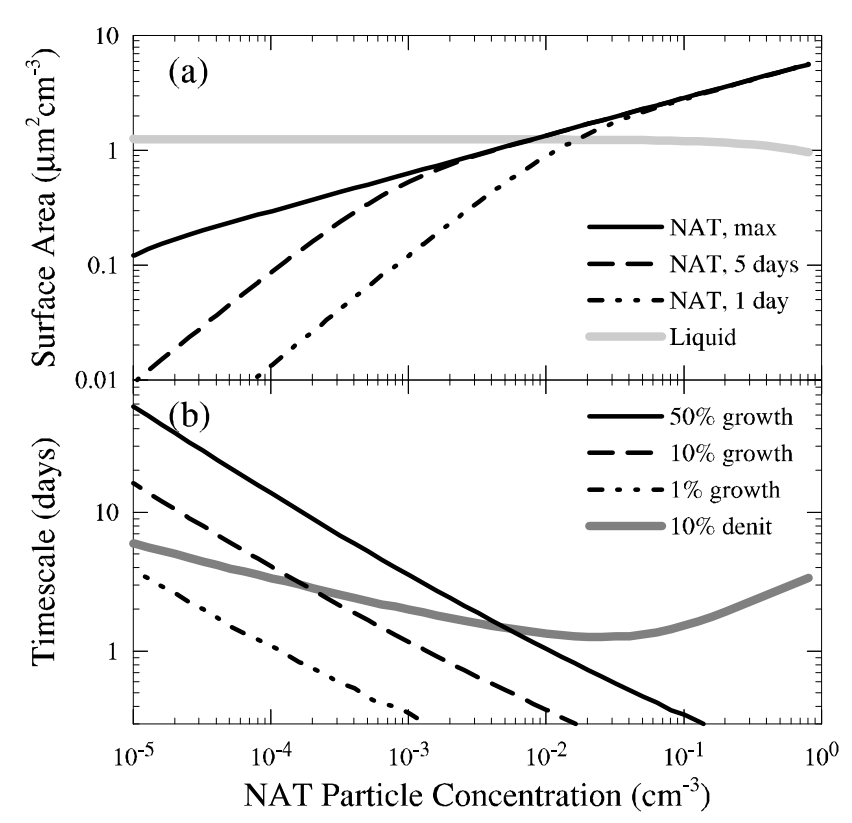

Fig. 3. Surface area density and growth for low NAT particle concentrations. (a) Surface area density. "NAT, max" shows the maximum (equilibrium) surface area density. "NAT, 1 day" and "NAT, 5 days" show microphysical model calculations (Drdla et al., 2002) after one and five days. The coexistent liquid surface area density is also shown. (b) Timescales for growth and denitrification. The growth curves show the time necessary for $50 \%, 10 \%$, and $1 \%$ of the $\mathrm{HNO}_{3}$ to condense. The denitrification curve shows the time necessary for $10 \%$ of the total $\mathrm{HNO}_{3}$ to sediment $1 \mathrm{~km}$. The assumed conditions for all calculations in this figure are temperature, $192 \mathrm{~K}\left(\sim\right.$ three kelvin below $\left.T_{\mathrm{NAT}}\right)$, potential temperature, $475 \mathrm{~K}$, 10 ppbv total $\mathrm{HNO}_{3}$, and 5 ppmv total $\mathrm{H}_{2} \mathrm{O}$. Particle altitude was kept constant for the entire calculation.

et al., 2005; Höpfner et al., 2009; Pitts et al., 2009, 2011; Khosrawi et al., 2011). Results from CALIPSO (CloudAerosol Lidar and Infrared Pathfinder Satellite Observations, Pitts et al., 2007, 2009) confirm that $T_{\mathrm{NAT}}$ is a poor quantitative proxy for the occurrence of PSC (where CALIPSO detects particle number densities $>3-5 \mathrm{~cm}^{-3}$ ). Using $T_{\mathrm{NAT}}$ in this way leads to a significantly overestimated PSC areal extent (see Fig. 2-13 in WMO, 2011).

Moreover, in laboratory experiments in the AIDA simulation chamber, NAT does not form even when supersaturations up to $S=26$ prevail for up to four hours. Solely the formation of nitric acid dihydrate was observed (Wagner et al., 2005). This observation is consistent with laboratory studies by Fox et al. (1995), who observed that, under stratospheric conditions, metastable nitric acid dihydrate always formed before NAT and persisted for long periods. The detection of mixtures of nitric acid dihydrate and NAT over Antarctica in remote sensing measurements was reported by Kim et al. (2006) based on remote sensing measurements. The microphysical processes hindering NAT formation remain uncertain (Peter and Grooß, 2012).
Finally, the large surface areas in the "NAT, Original" calculation are controlled by the assumed NAT particle concentration (Fig. 3a) and are only possible for NAT concentrations greater than $1 \mathrm{~cm}^{-3}$. The maximum surface area possible for a given $\mathrm{HNO}_{3}$ mixing ratio is the equilibrium surface area assuming that all available $\mathrm{HNO}_{3}$ condenses onto a specified number of particles. Assuming that all particles are of equal size (and noting that the total NAT volume is fixed), the surface area is proportional to $n^{1 / 3}$, where $n$ is the number density of particles (Fig. 3a).

However, the primary evidence for large NAT concentrations of $\sim 1 \mathrm{~cm}^{-3}$ comes from PSC observations (Dye et al., 1990) that have since been identified as liquid-phase STS not NAT (Carslaw et al., 1997a). Observations specifically of NAT particles frequently find much lower concentrations, $<10^{-2} \mathrm{~cm}^{-3}$ (e.g., Northway et al., 2002; Pitts et al., 2009; Lambert et al., 2012). Pitts et al. (2011) found that less than $15 \%$ of the CALIPSO PSC observations in the Arctic between 2006-2010 fall into the category of NAT particles ("Mix 2-enh") with a relatively high number density $\left(>0.1 \mathrm{~cm}^{-3}\right)$ that are embedded into an STS cloud. In the extremely cold Arctic winter period in January 2010, there were significantly more observations of this type of NAT particles (and also of ice PSCs) than was previously the case (Pitts et al., 2011), albeit at temperatures well below $T_{\mathrm{NAT}}$.

Furthermore, observations have shown that, for large-scale low temperature conditions, the NAT particle characteristics are at most $10^{-3} \mathrm{~cm}^{-3}$ during the first five days that PSCs spend below $T_{\mathrm{NAT}}$. One set of Arctic observations found NAT particle concentrations of $1.6 \times 10^{-4} \mathrm{~cm}^{-3}$ in air that had been at temperatures between $T_{\mathrm{NAT}}-3 \mathrm{~K}$ and $T_{\mathrm{NAT}}$ for $\sim 20 \mathrm{~h}$ (Voigt et al., 2005). In another set of observations, air that had been below $T_{\mathrm{NAT}}$ for one to five days contained NAT concentrations of $\sim 10^{-3} \mathrm{~cm}^{-3}$ (Larsen et al., 2004). These NAT particle concentrations are comparable to the concentrations used in the "NAT, Current" scenario (Fig. 2).

The discovery of very large NAT particles $(>5 \mu \mathrm{m}$ radius), commonly referred to as "NAT rocks" (Fahey et al., 2001; Fueglistaler et al., 2002), was crucial because these measurements provided the first conclusive evidence of large NAT particles with very low concentrations $\left(<10^{-3} \mathrm{~cm}^{-3}\right)$. In Arctic winter 1999/2000, "NAT rocks" were observed over many days and over large geographical regions, implying that such particles are probably widespread at sufficiently low temperatures, but had been undetectable with previous instrumentation.

The occurrence of "NAT rocks" is important for denitrification, i.e., for the permanent removal of $\mathrm{HNO}_{3}$ from the stratosphere. Large NAT particles, which can only form through a selective nucleation process, sediment rapidly, enabling efficient denitrification above the ice frost point. Based on theoretical arguments, Salawitch et al. (1989) had already suggested that NAT nucleation is selective thereby allowing denitrification to occur without significant dehydration. However, low NAT concentrations also have 
implications for heterogeneous chemistry. As the NAT particle concentration decreases, the maximum surface area density also decreases (Fig. 3a). For NAT concentrations below $10^{-2} \mathrm{~cm}^{-3}$, the liquid surface area density always exceeds the NAT surface area density.

Furthermore, growth of NAT particles is slow compared to the length of cold periods, especially in the Arctic (e.g., Peter, 1997; Dameris et al., 2007; Peter and Grooß, 2012). Slow growth of NAT particles was indeed observed by Biele et al. (2001) in lidar measurements in the Arctic. In Fig. 3, NAT growth rates are shown which were determined using a microphysical model of PSCs (Drdla et al., 2002). The model was initialised with a specified number of NAT particles, with initial radii of $0.1 \mu \mathrm{m}$. The temperature was kept constant at $192 \mathrm{~K}$ for the entire simulation. The chosen temperature maximises NAT growth rates (at lower temperatures, gas phase $\mathrm{HNO}_{3}$ is depleted by liquid phase $\mathrm{HNO}_{3}$ uptake, inhibiting NAT growth). Other parameters were also chosen to maximise particle growth, e.g., the $\mathrm{HNO}_{3}$ accommodation coefficient was assumed to be unity. Liquid particles were assumed to be simultaneously present in the microphysical simulations, assuming a fixed total (liquid and NAT) particle concentration of $10 \mathrm{~cm}^{-3}$; the mode radius of the liquid particles was $0.8 \mu \mathrm{m}$. At high NAT concentrations, the slight decrease in liquid surface area reflects the decreased liquid particle concentration. The assumed conditions are too warm for the formation of STS; at lower temperatures, STS formation will enhance the liquid surface area by a factor of ten.

Therefore, with decreasing concentration, NAT particles are increasingly unlikely to reach the theoretically possible maximum surface area densities (Fig. 3b). For concentrations of $\sim 10^{-4} \mathrm{~cm}^{-3}$, more than five days below $T_{\mathrm{NAT}}$ are necessary for NAT surface area densities to approach the maximum values. Observations show that NAT surface area densities are $\sim 0.005 \mu^{2} \mathrm{~cm}^{-3}$ in a 20-hour-old PSC (Voigt et al., 2005). With such slow growth, particles start sedimenting appreciably before all the available gas phase $\mathrm{HNO}_{3}$ condenses. Therefore, for sufficiently low particle concentrations, the theoretically possible surface area density is unlikely to be reached under stratospheric conditions.

Considered separately, either reduced surface area densities or humidity-dependent reaction probabilities are each sufficient to prevent NAT particles from dominating chlorine activation by heterogeneous chemistry. When combined ("NAT, Current" in Fig. 2), these two factors imply that NAT particles cannot be responsible for the onset of chlorine activation observed near $T_{\mathrm{NAT}}$. "NAT, Current" assumes a NAT surface area density of $0.1 \mu \mathrm{m}^{2} \mathrm{~cm}^{-3}$, consistent with a NAT concentration of $10^{-4} \mathrm{~cm}^{-3}$ after five days of continuous growth (Fig. 3a). The NAT reaction probabilities are the same as in the "NAT, New $\gamma$ " case. Even after five days below $T_{\mathrm{NAT}}$, NAT particles only activate less than $0.1 \%$ of the available chlorine. Over longer timescales, larger NAT surface area densities may be possible, but their chemical relevance is limited because, in the meantime, a substantial frac- tion of the chlorine tied up in reservoir species will have been activated by other particles.

\section{Heterogeneous chemistry on liquids}

Stratospheric liquid sulfate aerosol provides a large, ubiquitous surface area density $\left(\sim 1 \mu \mathrm{m}^{2} \mathrm{~cm}^{-3}\right)$ for heterogeneous reactions (e.g., Portmann et al., 1996; Carslaw et al., 1997a; Solomon, 1999). Chlorine activation reactions on liquid aerosol are humidity-dependent (Hanson et al., 1994; Carslaw and Peter, 1997; Shi et al., 2001; Sander et al., 2011), resulting in a steady increase in reactivity with decreasing temperature (Fig. 2, "Liquid"): at $\sim 195 \mathrm{~K}$, the reactivity exceeds 0.1 day $^{-1}$. For the "Liquid" calculation in Fig. 2, the aerosol composition was calculated using the parameterisation of Carslaw et al. (1995). The liquid reactivities used the formulation by Shi et al. (2001), as recommended in the most recent evaluation by the Jet Propulsion Laboratory (JPL) of data for use in atmospheric studies (Sander et al., 2011). This formulation provides the reactivity of binary $\mathrm{H}_{2} \mathrm{SO}_{4} / \mathrm{H}_{2} \mathrm{O}$ aerosol only. To calculate ternary aerosol reactivities, the reactivity was assumed to be the same as that for the binary aerosol particles which would form under the same conditions (i.e., with the same water activity). This assumption is supported by laboratory studies by Elrod et al. (1995), who found that $\gamma$-values for liquid $\mathrm{H}_{2} \mathrm{SO}_{4}$ $\mathrm{HNO}_{3}-\mathrm{HCl}-\mathrm{H}_{2} \mathrm{O}$ solutions for Reaction (R1) remain essentially unchanged when $\mathrm{HNO}_{3}$ uptake on the liquid particles is neglected. In this approximation, differences between binary and ternary reactivities are caused solely by differences in surface area.

Simultaneous measurements of stratospheric particles and chlorine activation in Antarctica in July 1994 at temperatures below about 195 K (Kawa et al., 1997; Del Negro et al., 1997) showed no NAT particles or corresponding surface area increase. Thus, while liquid aerosol chlorine activation may occur near the threshold temperature $T_{\mathrm{NAT}}$, the two activation mechanisms are distinct. With the constant reaction probabilities in the "NAT, Original" formulation, chlorine reactivity is controlled by particulate surface area alone. For liquid aerosol, in contrast, the controlling factors are reversed: the onset of activation is caused solely by reaction probability changes (which are driven by temperature change), while the surface area is nearly constant. Near $T_{\mathrm{NAT}}$ the aerosol contains a negligible fraction (less than one percent) of the total available $\mathrm{HNO}_{3}$. The $\mathrm{H}_{2} \mathrm{O}$ content is higher than at midlatitudes (thus enabling efficient chlorine reactions), but the surface area density has increased by less than $2 \%$. Large liquid surface area density enhancements only occur $4 \mathrm{~K}$ below $T_{\mathrm{NAT}}$, when $\mathrm{HNO}_{3}$ uptake converts the aerosol into an STS PSC. The reactivity for binary aerosol (Fig. 2, "Liquid (binary)"), where STS formation is disabled, is identical to the "Liquid" value at temperatures above $192 \mathrm{~K}$. The divergence between these two curves at low temperatures 
isolates the contribution of PSC formation (i.e., the enhancement of surface area density because of $\mathrm{HNO}_{3}$ uptake) to chlorine activation. Even without PSC formation, the aerosol reactivity exceeds 1 day $^{-1}$.

Simulations of winter-long evolution in a detailed PSC and chemistry model (Drdla et al., 2002; Drdla and Schoeberl, 2002 , see Sect. 5 below) corroborate these conclusions. Over an entire Arctic winter, NAT particles caused $2 \%$ of the total chlorine activation and STS PSCs $12 \%$; the remaining $86 \%$ was caused by cold binary aerosol. A second model simulation where only binary sulfate aerosol was assumed to be present (i.e., where PSC formation was suppressed) had chlorine activation that was nearly identical to the simulation with full PSCs (63.8\% versus $63.4 \%$ ). Even in the Antarctic, $58 \%$ of all chlorine activation is caused by binary aerosol in a simulation with full PSC formation; without PSCs, cold binary aerosol replaces the PSC contribution and the total chlorine activation is almost unchanged $(68.6 \%$ versus $68.1 \%$ ). PSCs make a contribution because they are present for periods of the winter, but under the same conditions, if the heterogeneous reactivity were limited to cold binary aerosol reactivity, it would be sufficient to rapidly activate any available chlorine. By the time PSCs form, activation is limited by the availability of reactants, not by the heterogeneous reaction rate. Thus, under these conditions, a reactivity of 1 day $^{-1}$ on cold binary aerosol has essentially the same effect on chlorine activation as a reactivity of 10 day $^{-1}$ on a PSC.

Although chlorine activation on cold binary aerosol may initiate near $T_{\mathrm{NAT}}$ (Fig. 2a), the similarity should not be used to estimate chlorine activation under other conditions, such as the denitrified conditions common in Antarctic springtime. When $\mathrm{HNO}_{3}$ is depleted, PSC formation is suppressed (Fig. 2b): $T_{\mathrm{NAT}}$ and the STS onset temperature are lower by $\sim 3 \mathrm{~K}$ and for the PSCs that do form their reduced surface area limits the reactivities. In contrast, the binary aerosol reactivity is unaffected by denitrification and therefore is identical for the conditions shown in Fig. 2a and b. In conformity with the liquid aerosol reactivities, observations confirm that chlorine activation is efficient under denitrified conditions, in both the Arctic (Hanisco et al., 2002) and Antarctic (Shindell and de Zafra, 1997). Since chlorine activation does not require NAT formation, $T_{\mathrm{NAT}}$ does not provide a reliable predictor of chlorine activation and subsequent ozone loss.

\section{The chlorine activation threshold: $T_{\mathrm{ACL}}$}

To describe how the onset of chlorine activation responds to changing conditions, it is useful to define a temperature threshold for the onset of chlorine activation, $T_{\mathrm{ACL}}$. The definition put forward here is based on liquid aerosol reactivities by requiring that a critical reactivity threshold must be exceeded for efficient activation. We adopt a reactivity threshold of 0.1 day $^{-1}$, which is the point at which detectable lev- els of active chlorine $(\sim 10 \%)$ are produced on timescales of one day. A chlorine activation of $10 \%$ is equivalent in the current atmosphere to about $0.35 \mathrm{ppbv}$ of $\mathrm{ClO}$, which is a clearly recognisable enhancement relative to background levels of $\sim 0.1 \mathrm{ppbv}$.

Using a reactivity of 0.1 day $^{-1}$ to define $T_{\mathrm{ACL}}$, its value was calculated employing the model by Drdla et al. (2002) for a wide range of stratospheric conditions. The parameters that were varied were $\mathrm{H}_{2} \mathrm{O}$ (range 1 to 20 ppmv), sulfate surface area $\left(0.1\right.$ to $\left.100 \mu \mathrm{m}^{2} \mathrm{~cm}^{-3}\right)$, potential temperature (375 to $700 \mathrm{~K}$ ), and $\mathrm{HNO}_{3}$ (1 to $20 \mathrm{ppbv}$ ). Calculations assuming both a ternary and a binary liquid solution were performed for each combination of $\mathrm{H}_{2} \mathrm{O}$, surface area, and potential temperature. All possible combinations of the parameters were examined; in total, $T_{\mathrm{ACL}}$ was calculated for more than 500000 different conditions. Across almost the full range of tested conditions, $T_{\mathrm{ACL}}$ occurs at temperatures higher than the onset of STS, and therefore $T_{\mathrm{ACL}}$ shows no significant dependence on $\mathrm{HNO}_{3}$. At $T_{\mathrm{ACL}}$ the average $\mathrm{HNO}_{3}$ weight percent of the liquid aerosol is $0.8 \%$; the surface area is on average $2 \%$ larger than the surface area at $210 \mathrm{~K}$.

Based on the model results, a parameterisation of $T_{\mathrm{ACL}}$ is deduced, where $T_{\mathrm{ACL}}$ depends only on $\mathrm{H}_{2} \mathrm{O}$, sulfate aerosol surface area density, and altitude (i.e., on the vertical coordinate), but has no dependence on $\mathrm{HNO}_{3}$ :

$$
T_{\mathrm{ACL}}=a+b \cdot v+c \cdot v^{2}+d \cdot s+e \cdot s^{2}+f \cdot s^{3}+g \cdot v \cdot s+h \cdot v \cdot s^{2}
$$

with

$v=\ln \left(\left[\mathrm{H}_{2} \mathrm{O}\right] \cdot z^{\alpha}\right)$

$s=\ln (\mathrm{SA})$

where $z$, the input vertical coordinate, can be either the potential temperature $(\theta)$ or pressure $(p)$. Here, $\left[\mathrm{H}_{2} \mathrm{O}\right]$ is the $\mathrm{H}_{2} \mathrm{O}$ molar mixing ratio in ppmv (range 1 to $20 \mathrm{ppmv}$ ), $\mathrm{SA}$ is the sulfate surface area density at $210 \mathrm{~K}$ in $\mu \mathrm{m}^{2} \mathrm{~cm}^{-3}$ (range 0.1 to $100 \mu \mathrm{m}^{2} \mathrm{~cm}^{-3}$ ), $\theta$ is the potential temperature in kelvin (range 375 to $700 \mathrm{~K}$ ) and $p$ is the pressure in $\mathrm{hPa}$ (range $\sim 10$ to $100 \mathrm{hPa}$ ). Equation (2) can be applied in regions where the maximum solar elevation is less than $20^{\circ}$ (i.e., the solar zenith angle is greater than $70^{\circ}$ ); the coefficients used are listed in Table 1. Different values of the coefficients are found for the choice of vertical coordinate, either potential temperature or pressure.

The parameterisation of $T_{\mathrm{ACL}}$ (Eq. 2) was deduced using a least-squares fit. Two separate fits were created to allow either potential temperature or pressure to be used as the vertical coordinate. Both fits match the chemical model results for the temperature threshold of chlorine activation with comparable accuracy. For most conditions (potential temperature 400 to $620 \mathrm{~K}$, surface area 0.2 to $15 \mu \mathrm{m}^{2} \mathrm{~cm}^{-3}$, water vapour 2 to $16 \mathrm{ppmv}$ ), the difference between model and fit is less than $0.25 \mathrm{~K}$. Over the full range of conditions, the root mean square difference between model and fit is $0.21 \mathrm{~K}$. This definition of the threshold temperature $T_{\mathrm{ACL}}$ yields $194.5 \mathrm{~K}$ at 
Table 1. Coefficients for the parameterisation of $T_{\mathrm{ACL}}$ in Eq. (2). Parameters are valid for potential temperature $\theta$ in kelvin and for pressure $p$ in $\mathrm{hPa}$ for the potential temperature rage $375-700 \mathrm{~K}$ corresponding to a pressure range of $\sim 10-100 \mathrm{hPa}$.

\begin{tabular}{lrr}
\hline & $z=\theta$ & $z=p$ \\
\hline$\alpha$ & -4.0628 & 1.1612 \\
$a$ & 480.781 & 170.216 \\
$b$ & 18.569 & 2.8625 \\
$c$ & 0.2711 & 0.197 \\
$d$ & 6.4481 & 0.1587 \\
$e$ & 1.9915 & -0.2457 \\
$f$ & 0.05857 & 0.04705 \\
$g$ & 0.2201 & 0.1665 \\
$h$ & 0.07958 & 0.05914 \\
\hline
\end{tabular}

typical stratospheric conditions (Fig. 2a), which is consistent with observations of increased $\mathrm{ClO}$ at $195 \mathrm{~K}$ (Toohey et al., 1993; Webster et al., 1993; Kawa et al., 1997).

The formulation of $T_{\mathrm{ACL}}$ as a threshold temperature for the onset of chlorine activation does not take into account chlorine deactivation, which counteracts chlorine activation, if the activation does not occur during polar night. While the formation of $\mathrm{HCl}$ from the reaction of atomic chlorine with $\mathrm{CH}_{4}$ becomes significant only for very low ozone concentrations (Douglass et al., 1995; Grooß et al., 1997, 2011) and is therefore not relevant for the onset of chlorine activation, the re-formation of $\mathrm{ClONO}_{2}$ from activated $\mathrm{ClO}$ may counteract chlorine activation. However, for the low solar elevation (large solar zenith angle) conditions during polar winter, the formation of $\mathrm{ClONO}_{2}$ is strongly suppressed because of low concentrations of $\mathrm{NO}_{2}$. The reservoir species for $\mathrm{NO}_{2}$, $\mathrm{N}_{2} \mathrm{O}_{5}$, is converted to $\mathrm{HNO}_{3}$ via heterogeneous reactions on the background sulfate aerosol and the re-formation of $\mathrm{NO}_{2}$ from $\mathrm{HNO}_{3}$ via reaction with $\mathrm{OH}$, and photolysis is rather slow for low solar elevation (or large solar zenith angle).

Moreover, gas phase concentrations of $\mathrm{HNO}_{3}$ are strongly suppressed in the presence of PSCs by the uptake of $\mathrm{HNO}_{3}$ in PSC particles, further limiting the efficiency of deactivation. Thus, under conditions where chlorine deactivation through the formation of $\mathrm{ClONO}_{2}$ is significant, distinguishing between PSCs, which take up $\mathrm{HNO}_{3}$ from the gas phase, and cold binary aerosol particles, which do not, is important. Through the reduction of $\mathrm{HNO}_{3}$ in the gas phase, PSCs slow down deactivation, which is not the case for cold binary aerosol.

Under realistic conditions in the polar stratosphere in winter, circumstances are complex. If rapid cooling to several degrees below $T_{\mathrm{ACL}}$ occurs, the heterogeneous chlorine activation rate will rapidly exceed the activation rate prevailing at $T_{\mathrm{ACL}}$ by a large amount (Fig. 2). Further, there are conditions under which the re-formation of $\mathrm{ClONO}_{2}$ will enhance chlorine activation rather than leading to deactivation. This is the case when temperatures remain below $T_{\mathrm{ACL}}$ long enough for $\mathrm{ClONO}_{2}$ to be completely depleted while the $\mathrm{HCl}$ reservoir is not entirely activated. Under these conditions, the reformation of $\mathrm{ClONO}_{2}$ provides a reaction partner for $\mathrm{HCl}$ so that the heterogeneous activation can proceed further instead of being stopped by the lack of a reaction partner for $\mathrm{HCl}$ (e.g., Müller et al., 1994).

However, when the $\mathrm{HCl}$ reservoir is strongly depleted, the production of $\mathrm{NO}_{2}$ under activated conditions leads to the formation of $\mathrm{ClONO}_{2}$ and thus to deactivation even though the heterogeneous reaction rates are large. Under such conditions, deactivation would occur at temperatures below $T_{\mathrm{ACL}}$. On the other hand, for conditions of very low ozone mixing ratios (below 0.5 ppmv) in Antarctic spring, a balance is maintained by the gas-phase production of $\mathrm{HCl}$ and $\mathrm{HOCl}$ followed by heterogeneous reactions of these two compounds leading to no net change of active chlorine for a certain period (Grooß et al., 2011).

Therefore, tests have been done using a full photochemical model (Drdla and Schoeberl, 2002) to determine the conditions under which chlorine deactivation is too slow to compete with heterogeneous activation, assuming no denitrification. The criteria used were that the timescale for deactivation was more than 15 days (taking into account all possible chlorine deactivation pathways) and that the amount of available $\mathrm{NO}_{\mathrm{x}}\left(\mathrm{NO}+\mathrm{NO}_{2}\right)$ was less than $0.5 \mathrm{ppbv}$. Under a range of stratospheric conditions, these conditions were always met by air parcels in which the noon time solar elevation was less than $20^{\circ}$ (i.e., the solar zenith angle is greater than $70^{\circ}$ ). Thus, when solar elevation is less than $20^{\circ}$, deactivation is too slow to significantly influence $T_{\mathrm{ACL}}$, which covers the region and time period of interest for the onset of polar chlorine activation.

Further, model simulations confirm that $0.1 \mathrm{day}^{-1}$ and $T_{\text {ACL }}$ represent meaningful thresholds for polar ozone loss. Winter-long simulations of the 1999-2000 Arctic winter (see Sect. 5 below) were examined to determine the model conditions necessary for enhanced ozone loss. Figure 4 shows, for each individual model air parcel in the "FullPSC" simulation, a comparison of the ozone loss over winter and early spring with the lowest temperature to which the air parcel was exposed for one day. Exposure for one day was used instead of the instantaneous minimum temperature because activation does not occur instantaneously. Enhanced ozone loss is detectable starting in air parcels that have spent one day below $T_{\mathrm{ACL}}$.

The most obvious difference between $T_{\mathrm{ACL}}$ and $T_{\mathrm{NAT}}$ is the sensitivity to sulfate surface area density (Fig. 5). Large volcanic eruptions can increase stratospheric aerosol surface areas, causing enhanced chlorine activation (Toon et al., 1993) and ozone loss (e.g., Hofmann and Solomon, 1989; Hofmann and Oltmans, 1993; Portmann et al., 1996; Deshler et al., 1996; Tabazadeh et al., 2002; Rex et al., 2004; Solomon et al., 2005; Tilmes et al., 2008b).

Portmann et al. (1996) investigated the interannual variability of Antarctic ozone loss and emphasised the 


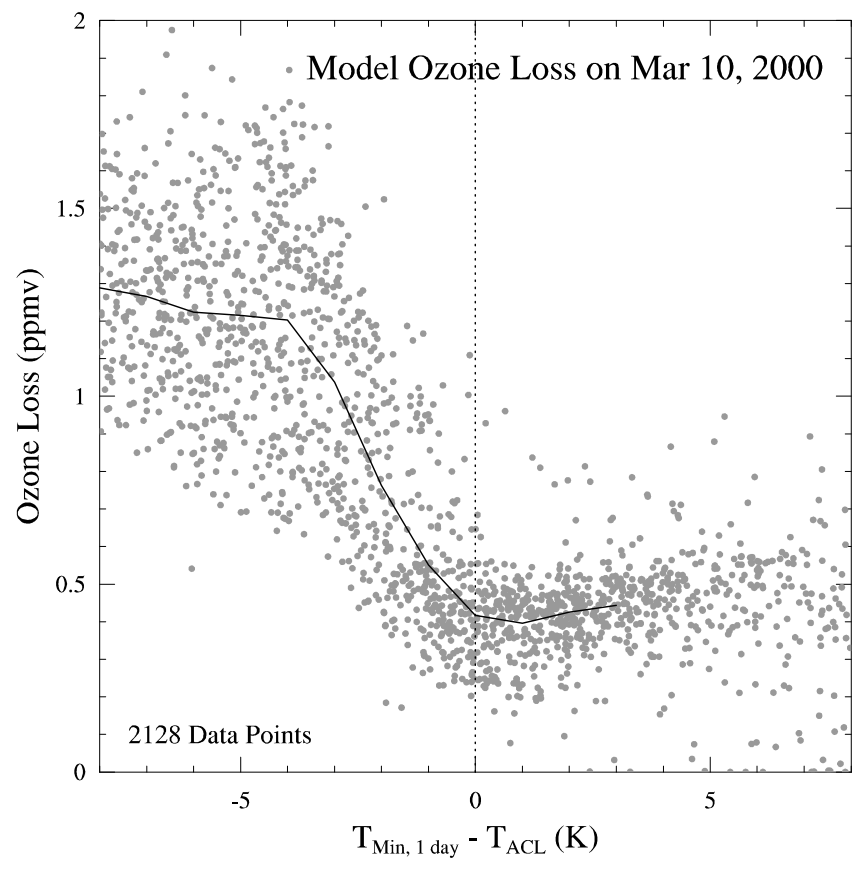

Fig. 4. Ozone loss as a function of the minimum temperature (relative to $T_{\mathrm{ACL}}$ ) to which the air had been exposed for one day. Results are shown for the Arctic "FullPSC" scenario (see Table 2). Ozone loss is the total chemical loss from 1 November to 10 March. Each point represents one simulated air parcel; all 2128 air parcels from 400 to $600 \mathrm{~K}$ are shown. The solid line is the average ozone loss in each $1 \mathrm{~K}$ temperature bin.

importance of sulfate aerosol for heterogeneous chlorine activation. They demonstrated that the inter-annual variability and, in particular, the increases in Antarctic ozone depletion in the 1980s could only be reproduced by a model that included the observed interannual variation of stratospheric aerosol. Furthermore, Portmann et al. (1996) found that the increase in stratospheric aerosol caused by the eruption of Mt Pinatubo in 1991 primarily affected the vertical extent of the ozone hole in their simulations since the simulated ozone loss at the altitudes with the strongest loss was nearly complete, even when the volcanically enhanced aerosol was not considered.

$T_{\mathrm{ACL}}$ and $T_{\mathrm{NAT}}$ are both dependent upon $\mathrm{H}_{2} \mathrm{O}$ (Fig. 5c) and potential temperature (Fig. 5d), but $T_{\mathrm{ACL}}$ shows somewhat greater sensitivity to both variables. The vertical sensitivity is further enhanced for $T_{\mathrm{ACL}}$ by incorporating a gradient in the aerosol surface area density (Fig. 5d). Even moderate differences between $T_{\mathrm{ACL}}$ and $T_{\mathrm{NAT}}$ have consequences, for example when comparing the areal extent of temperatures below each threshold for an Arctic winter (Fig. 6). For the example of the cold Arctic winter 2004-2005, the onset of chlorine activation is estimated to occur two weeks earlier based on $T_{\mathrm{NAT}}$ than based on $T_{\mathrm{ACL}}$ and extends to higher altitudes throughout the winter. The deduced total areal extent of chlorine activation is $50 \%$ smaller for $T_{\mathrm{ACL}}$ than for $T_{\mathrm{NAT}}$ at $22 \mathrm{~km}$, even though $T_{\mathrm{ACL}}$ is only $2 \mathrm{~K}$ lower than $T_{\mathrm{NAT}}$. In regions with the most direct impact on column ozone, namely lower altitudes and late in the winter, $T_{\mathrm{ACL}}$ yields a considerably greater estimate of chlorine activation than $T_{\mathrm{NAT}}$.

\section{Model simulations of the evolution of microphysics and chlorine activation over polar winter}

A model with full PSC microphysics, heterogeneous chemistry, and gas phase chemistry (Drdla et al., 2002; Drdla and Schoeberl, 2002) was employed to further investigate several aspects of this study. The model was used to simulate both the 1999-2000 Arctic winter and the 2000 Antarctic winter. The simulations for the 1999-2000 Arctic winter use the same methodology as previous studies (Drdla et al., 2002; Drdla and Schoeberl, 2002). A comparable methodology was adopted for the Antarctic winter, where 3517 trajectories were simulated, extending from 15 April 2000 to 15 November 2000, ranging in potential temperature from $400 \mathrm{~K}$ to $750 \mathrm{~K}$ on 15 July. Table 2 summarises the microphysical scenarios used in this study.

The "FullPSC" scenario is designed as the most realistic scenario describing PSC characteristics. In this case, chlorine will be activated on all particles present, thus most closely resembling the conditions in the real stratosphere. The assumptions on microphysics are the same as in the "HetFrzB" scenario, which was found to best match measurements in both the Arctic (Drdla et al., 2002) and Antarctic (Benson et al., 2006). The formation of a small $\left(<10^{-2} \mathrm{~cm}^{-3}\right)$ concentration of NAT particles allows realistic denitrification to occur. The remaining fraction of the particles is liquid, with $\mathrm{HNO}_{3}$ uptake to form STS PSCs at lower temperatures. In the Antarctic, significant dehydration is simulated as a result of widespread ice PSC formation.

All other scenarios were designed as sensitivity studies testing the impact of particular aspects of microphysics on chlorine activation and ozone loss. The second scenario, "Liquid", was used to isolate the effects of denitrification and dehydration. This scenario included only liquid-phase particles (no NAT or ice PSCs), but ternary solution formation was allowed, so STS PSCs were prevalent. As discussed by Drdla and Schoeberl (2002), maximum chlorine activation is almost identical in the "Liquid" and "FullPSC" simulations. This result is expected from the knowledge obtained through laboratory studies on the reactivities of liquid aerosol particles (Ravishankara and Hanson, 1996; Solomon, 1999). The differences in ozone loss (Table 2) can be attributed to the effects of denitrification and dehydration, which are suppressed in the "Liquid" simulation.

The remaining scenarios further alter the "Liquid" scenario to examine the chlorine activation processes specifically. "LiqBin" has only binary solution liquid aerosol particles. Without any $\mathrm{HNO}_{3}$ uptake, STS PSC formation is suppressed and the liquid particle surface area density is not 


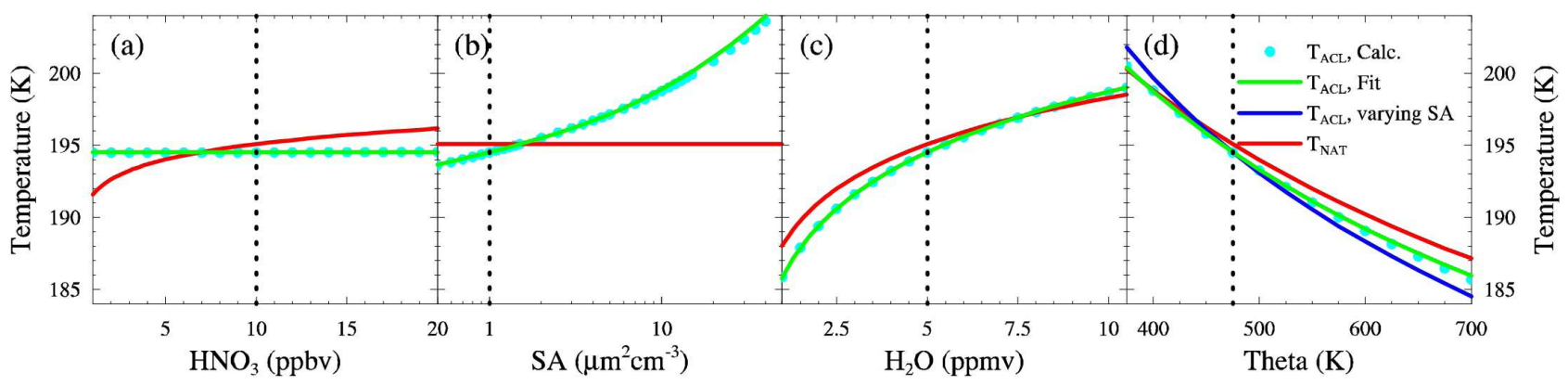

Fig. 5. Comparison of the chlorine activation temperature, $T_{\mathrm{ACL}}$ (calculated values: dots; Eq. (2): green line), with $T_{\mathrm{NAT}}$ (red line). The vertical dashed lines mark the standard conditions of 10 ppbv $\mathrm{HNO}_{3}, 1 \mu^{2} \mathrm{~cm}^{-3}$ surface area density, $5 \mathrm{ppmv} \mathrm{H}_{2} \mathrm{O}$, and $475 \mathrm{~K}$; one parameter is varied in each panel. (a) $\mathrm{HNO}_{3}$. (b) Sulfate aerosol surface area density. (c) $\mathrm{H}_{2} \mathrm{O}$. (d) Potential temperature. For (d), the dots and the solid green line assume a constant $1 \mu \mathrm{m}^{2} \mathrm{~cm}^{-3}$ surface area density; the blue line incorporates a simplified aerosol surface area density profile. The simplified surface area density (SA) profile is constructed by assuming that the surface area density varies according to the air

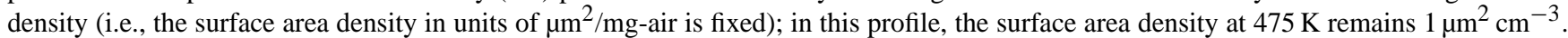
The resulting surface area density profile is comparable to measured values at background conditions (Bauman et al., 2003).

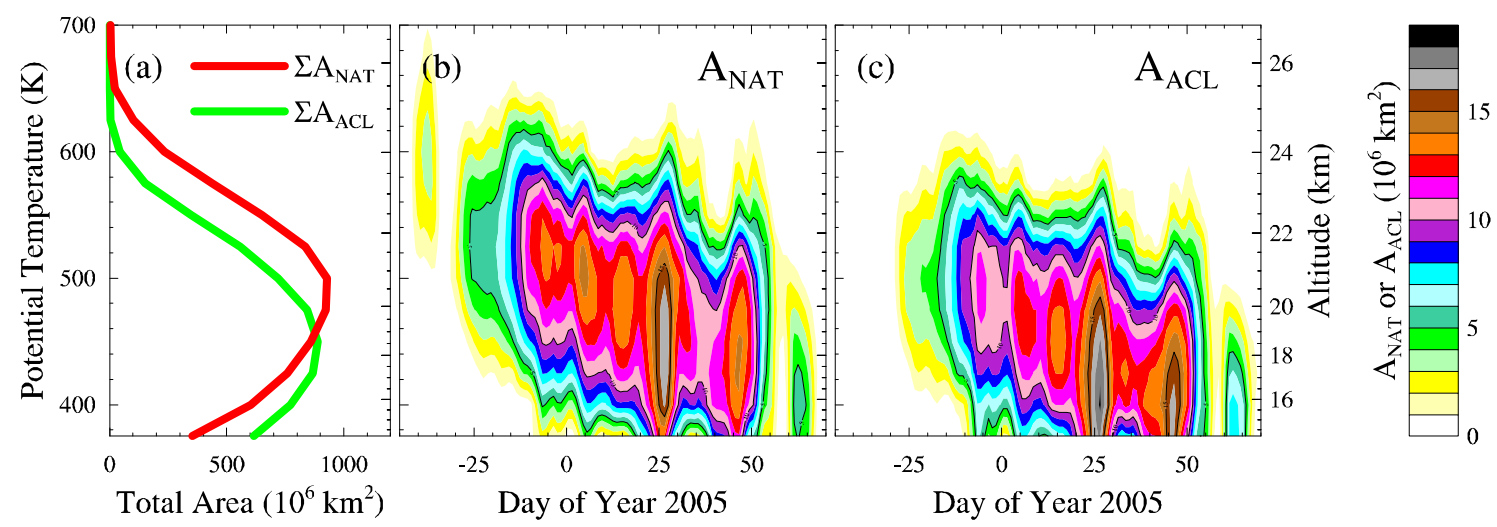

Fig. 6. Comparison for the 2004-2005 Arctic winter of the areal extent of temperatures below $T_{\mathrm{NAT}}$ and $T_{\mathrm{ACL}}$, labelled $A_{\mathrm{NAT}}$ and $A_{\mathrm{ACL}}$, respectively. (a) Winter-long integrals of $A_{\mathrm{ACL}}$ and $A_{\mathrm{NAT}}$. (b) Daily values of $A_{\mathrm{NAT}}$. (c) Daily values of $A_{\mathrm{ACL}}$. The calculations are based on daily UK Met Office analysis temperatures, interpolated onto potential temperature surfaces. Both $A_{\mathrm{ACL}}$ and $A_{\mathrm{NAT}}$ calculations assume 5 ppmv $\mathrm{H}_{2} \mathrm{O}$. For $A_{\mathrm{NAT}}, \mathrm{HNO}_{3}$ is initialised from a MkIV balloon profile (Toon et al., 1999) measured on 3 December 1999 (Salawitch et al., 2002; Müller et al., 2002); denitrification is not incorporated into the calculation. For $A_{\mathrm{ACL}}$, the "varying SA" sulfate surface area density profile was used, similar to Fig. 5d.

enhanced at low temperatures. The reactivity corresponds to the "Liquid (binary)" calculation in Fig. 2. Chlorine activation and ozone loss are nearly identical in "Liquid" and "LiqBin", showing that the chlorine activation is not sensitive to the PSC characteristics or the surface area density enhancements caused by the PSCs. Under the conditions where PSCs normally form, reactivities on binary aerosol alone are fast enough to activate the available chlorine.

In "LiqTACL" and "LiqTACL2", the conditions along each simulated trajectory were artificially altered to further constrain the importance of PSC-type temperatures. For "LiqTACL", the temperature was set equal to $T_{\mathrm{ACL}}$ during the periods when the temperature would normally have been less than $T_{\mathrm{ACL}}$. Temperatures were not altered at conditions above $T_{\mathrm{ACL}}$. Similarly for "LiqTACL2", the minimum temperature was set to $2 \mathrm{~K}$ below $T_{\mathrm{ACL}}$. These temperatures are high enough to prevent STS PSC formation, i.e., the liquid surface area density never increases above background levels. In addition, the reactivity of the liquid aerosol is effectively capped: in "LiqTACL" the reactivity never exceeds 0.1 day $^{-1}$ and for "LiqTACL2" the maximum is roughly 0.3 day $^{-1}$. Chlorine activation and ozone loss are reduced in these simulations in accordance with earlier studies that emphasised the importance of the rate of heterogeneous reactions for the maintenance of high levels of active chlorine into spring (Portmann et al., 1996; Carslaw et al., 1997b; Drdla and Schoeberl, 2002). However, even with these substantial perturbations of the chemistry, both chlorine activation and ozone loss remain significant.

Therefore, "LiqTACL" shows that exposure to temperatures at or below $T_{\mathrm{ACL}}$, with reactivities no greater than 0.1 day $^{-1}$, is by itself responsible for most of the model's 
Table 2. Summary of model simulations of winter-long evolution. Five scenarios were examined, all of them for one Arctic and one Antarctic winter, using a model with complete chemistry and microphysics (Drdla et al., 2002; Drdla and Schoeberl, 2002). One case ("FullPSC") is designed to be as realistic as possible; the other four cases are purely designed as sensitivity tests. Averages over the vortex (both horizontally and vertically from 425 to $525 \mathrm{~K}$ ) are shown. Chlorine activation dates were chosen to be near the peak in chlorine activation and before the effects of denitrification had significant effects. The date chosen for ozone loss in the Arctic is immediately before the vortex final warming; in the Antarctic, it is after ozone loss has maximised.

\begin{tabular}{llcccc}
\hline Scenario & Key Features & \multicolumn{2}{c}{$\begin{array}{c}\text { Vortex-Averaged } \\
\text { Chlorine Activation (\%) }\end{array}$} & $\begin{array}{c}\text { Vortex-Averaged } \\
\text { Ozone Loss }(\%)\end{array}$ \\
\hline & & Arctic & Antarctic & Arctic & Antarctic \\
10 Mar & 1 Nov \\
\hline FullPSC & All PSC types possible, denitrification occurs & 64 & 68 & 36 & 87 \\
Liquid & Liquid particles only, no denitrification & 64 & 68 & 33 & 85 \\
LiqBin & Binary liquid only (no STS PSCs) & 64 & 69 & 33 & 84 \\
LiqTACL & Temperature $>T_{\mathrm{ACL}}$ & 51 & 50 & 27 & 50 \\
LiqTACL2 & Temperature $>T_{\mathrm{ACL}}-2$ & 59 & 61 & 31 & 64 \\
\hline
\end{tabular}

chlorine activation and ozone loss. Allowing binary liquid aerosol reactivity values greater than 0.1 day $^{-1}$ ("LiqBin" simulation), as is normally predicted below $T_{\mathrm{ACL}}$ without any required changes in aerosol surface area density, enhances the chlorine activation, but only by $18-20 \%$. Surface area density increases, due to STS, NAT, or ice PSCs ("Liquid" and "FullPSC" simulations), are not necessary to account for any of the modelled chlorine activation. NAT and ice PSC formation only alter the model chemistry through denitrification and dehydration.

A greater reactivity on NAT than adopted here (Fig. 2) would result if temperature-dependent $\gamma$-values based on the laboratory measurements by Hanson and Ravishankara (1993) were employed (Carslaw and Peter, 1997) and if a greater number density of NAT particles was assumed. An upper limit for the chlorine reactivity on NAT could be obtained by assuming a NAT number density of $1 \mathrm{~cm}^{-3}$ and using the temperature-dependent $\gamma$-value provided by Carslaw and Peter (1997) based on the measurements by Hanson and Ravishankara (1993). A realistic assumption would be that NAT forms at about $\sim 3 \mathrm{~K}$ supercooling. The reactivity on NAT resulting from these assumptions is very close (for $T<193 \mathrm{~K}$ ) to the reactivity in binary aerosol (Shi et al., 2001) assuming no $\mathrm{HNO}_{3}$ uptake from the gas phase (Peter and Grooß, 2012). Therefore, assuming an upper limit for NAT reactivity and zero reactivity on liquid particles would result in a very similar chlorine activation and ozone loss in the model as in the case "LigBin" (Table 2).

In interpreting the model results presented in Table 2, it must be taken into account that, although designed as the most realistic case, the numbers calculated for the "FullPSC" case are dependent on parameters affected by uncertainties such as the initial $\mathrm{HCl}$ to $\mathrm{ClONO}_{2}$ ratio, the extent of denitrification, the temperature history, and the accuracy to which reaction rate constants are known (see also Drdla and Schoeberl, 2002). Furthermore, in order to assess the quality of simulated ozone loss, uncertainties in gas phase chemistry are important in addition to uncertainties in heterogeneous chlorine activation (Kawa et al., 2009). The focus here is on the relative changes to the results obtained assuming various scenarios to test the sensitivity of chlorine activation and ozone loss to microphysical processes.

\section{Discussion}

\subsection{Heterogeneous chemistry in models}

Numerous models at a variety of spatial scales incorporate stratospheric chemistry, leading to a range of different assumptions about heterogeneous chemistry and about the onset of chlorine activation (e.g., Krämer et al., 2003; Eyring et al., 2010; Morgenstern et al., 2010). Substantially different model results regarding the onset and the spatial and temporal extent of chlorine activation emerge depending on these assumptions. It is important whether PSC formation in the model is assumed at $T_{\mathrm{NAT}}$, whether supercooling is required and whether a temperature dependence of the reaction probabilities $\gamma$ is implemented in the model (Fig. 5 in Krämer et al., 2003). Model simulations that assume the onset of chlorine activation at $T_{\mathrm{NAT}}$ (i.e., at the NAT equilibrium temperature) tend to overestimate the magnitude, spatial extent and duration of chlorine activation in comparison to observations of halogen species in the stratosphere (Engel et al., 2000; Santee et al., 2008).

Further, models with full PSC microphysics introduced small NAT concentrations (Davies et al., 2005; Grooß et al., 2005) in order to produce realistic denitrification. As long as most particles remain liquid, the chlorine activation rates in these models are rather similar in magnitude to those deduced from the liquid aerosol chemistry adopted here. The only implication comes when interpreting the model results, since, even with aerosol-dominated chemistry, analyses have 
still attributed the chlorine activation to PSCs (Drdla and Schoeberl, 2002).

Other stratospheric models that cannot incorporate detailed particle chemistry instead use simplified parameterisations that are often derived from NAT-based assumptions. Assumptions employed are that NAT particles replace liquid particles below $T_{\mathrm{NAT}}$; that NAT particles have large surface area densities (i.e., concentrations of $1 \mathrm{~cm}^{-3}$ or radii of $1 \mu \mathrm{m}$ ); and that reaction probabilities are constant on NAT (as recommended by the JPL evaluation, Sander et al., 2006, 2011).

However, the formation of NAT particles requires large supersaturations to prevail (Schlager et al., 1990; Dye et al., 1990, 1992; Peter, 1997; Wagner et al., 2005) and observational evidence for NAT concentrations of $\sim 1 \mathrm{~cm}^{-3}$ is very limited. Furthermore, there is evidence from laboratory studies that reaction probabilities on solid particles are dependent on humidity, and thus on temperature (Abbatt and Molina, 1992; Hanson and Ravishankara, 1993; Carslaw and Peter, 1997).

Even with aerosol chemistry incorporated into a model, these assumptions can result in NAT-controlled heterogeneous chemistry. For example, the well-established SLIMCAT chemical transport model (Chipperfield et al., 2005) introduced an improved denitrification scheme with large NAT particles, but still includes a second mode of numerous small NAT particles that determine the heterogeneous chemistry (Davies et al., 2002). Chemistry climate models used for assessments of stratospheric ozone loss (WMO, 2007; Eyring et al., 2007, 2010) frequently adopt even simpler heterogeneous chemistry schemes. Although the conditions at which various types of PSCs condense and evaporate vary between CCMs, the simplest assumption, namely that PSCs are formed at the saturation points of $\mathrm{HNO}_{3}$ over NAT and $\mathrm{H}_{2} \mathrm{O}$ over water-ice, is made in most current state-of-theart CCMs (Eyring et al., 2010; Morgenstern et al., 2010). However, there are models that allow for NAT and ice supersaturation (Pitari et al., 2002; Garcia et al., 2007; Schraner et al., 2008) or that allow NAT formation only on ice or preexisting NAT particles (Buchholz, 2005). For chemistry calculations, an assumption that possibly leads to a more realistic description of chlorine activation would be to assume that NAT particles are never present, and rely instead solely upon liquid aerosol for chlorine activation. The latter approach has indeed been adopted for the Canadian Middle Atmosphere Model (Hitchcock et al., 2009).

Some models, for example, numerical weather prediction models which assimilate ozone, have implemented simplified chemistry schemes that explicitly use $T_{\mathrm{NAT}}$ to predict chlorine activation. These assimilation schemes treat chlorine activation by considering a "cold tracer" that is turned on below $T_{\mathrm{NAT}}$ (Hadjinicolaou et al., 1997; Eskes et al., 2003, 2005; Geer et al., 2006). The excessively fast activation that, in this way, is assumed to occur immediately at $T_{\mathrm{NAT}}$ may explain the overprediction of ozone loss that has been noted with these models (Eskes et al., 2005). If such simple parameterisations were based on $T_{\mathrm{ACL}}$ they should provide a more realistic chlorine activation without additional computational expense.

\subsection{Metrics for polar ozone loss}

The chlorine activation threshold $T_{\mathrm{NAT}}$ has also been used as a metric for examining interannual variability in ozone loss (Rex et al., 2004, 2006; Tilmes et al., 2004) and evaluating model performance (Chipperfield et al., 2005; Douglass et al., 2006). However, by using $T_{\mathrm{NAT}}$ these analyses do not accurately represent the processes controlling chlorine activation. For a few years now, observational estimates of vortex-wide PSC coverage have been available from the CALIPSO experiment (Pitts et al., 2007, 2009, 2011). These measurements show that the area in which PSCs are observed is significantly smaller than it would be if inferred from $T_{\mathrm{NAT}}$. The fact that $T_{\mathrm{ACL}}$ and $T_{\mathrm{NAT}}$ take similar values at altitudes of about $20 \mathrm{~km}(\sim 475 \mathrm{~K})$ explains why, despite the deficits of $T_{\text {NAT }}$ stated above, many studies based on $T_{\text {NAT }}$ were able to reach valid and robust conclusions on heterogeneous chlorine activation.

Replacing $T_{\mathrm{NAT}}$ with $T_{\mathrm{ACL}}$ provides a more robust scientific basis for the definition of the activation transition temperature. First studies that use $T_{\mathrm{ACL}}$ as the threshold for chlorine activation have recently been reported (Tilmes et al., 2007, 2008a; Feck et al., 2008; Tilmes et al., 2009). Tilmes et al. (2009) found that metrics based on $T_{\mathrm{ACL}}$ allowed a better description of observed Arctic ozone loss than metrics based on $T_{\mathrm{NAT}}$.

PSC-based assumptions about chlorine activation alter perceptions of how various factors influence polar ozone loss. One example is the inference that denitrification reduces ozone loss: if PSCs control chemistry, then suppression of PSCs in springtime denitrified conditions could lead to less efficient chlorine activation. However, liquid aerosol reactivities and thus $T_{\mathrm{ACL}}$ are insensitive to $\mathrm{HNO}_{3}$, allowing chlorine activation to remain efficient even in denitrified conditions.

\subsection{Outlook}

Arguably, this paper poses more questions than it answers. In this section, we discuss the necessary steps to make progress with answering these questions. First, the relative importance of heterogeneous reactions on various surfaces for chlorine activation should be tested through case studies. It will be important to select cases where constraints on the temporal development of the chlorine reservoir species $\mathrm{HCl}$ and $\mathrm{ClONO}_{2}$ and of active chlorine $\left(\mathrm{ClO}, \mathrm{Cl}_{2} \mathrm{O}_{2}\right)$ are available (e.g., Jones et al., 1990b; Toohey et al., 1993; Kawa et al., 1997; Jaeglé et al., 1997; Woyke et al., 1999; Vogel et al., 2003; Stimpfle et al., 2004; Wilmouth et al., 2006; SumińskaEbersoldt et al., 2012). Such studies would make it possible to both address the question of which surfaces are 
responsible for activation in a particular case and to test the sensitivity of the observed activation to the heterogeneous reactivity. Of particular interest would be the case of initial activation, i.e., a case when, for the first time in winter, air masses cool below the threshold for chlorine activation. Recently, Wegner et al. (2012) reported results of a model simulation of airborne $\mathrm{ClO}$ measurements at about $475 \mathrm{~K}$ in the Arctic vortex in March 2005 and January 2010. They found that heterogeneous reactions on cold binary aerosol particles were sufficient to explain the observed chlorine activation and that results hardly changed for a full PSC simulation, where surface area was enhanced through uptake of $\mathrm{HNO}_{3}$.

Second, heterogeneous reactivity might be "saturated" in the sense that it exceeds the reactivity required for full activation in the centre of the ozone loss region, but not at the top and bottom of the loss region. Thus, it will be important to scrutinise the importance of the various heterogeneous surfaces to explain the full height profile of ozone loss. Such studies will also need to take into account the great impact of uncertainties in gas phase chemistry on predictions of ozone loss (Kawa et al., 2009).

Third, the long-term development of polar ozone loss especially the Antarctic ozone hole - and its dependence on heterogeneous reactivity needs to be investigated. This will allow the relative importance of various heterogeneous reactions for chlorine activation and polar ozone loss to be tested under conditions of relatively low stratospheric chlorine in the early 1980s, of maximum chlorine around 2000, and of a decreasing stratospheric chlorine burden after the year 2000 (WMO, 2011).

Such studies will further allow the importance of volcanically enhanced stratospheric sulfate aerosol for the development of polar ozone over the past decades (Portmann et al., 1996) to be revisited, based on an improved understanding of PSC formation and the temperature dependence of heterogeneous reactions (e.g., Peter and Grooß, 2012), as well as on recent recommendations of heterogeneous reactivity (Sander et al., 2011). Quantifying the impact of volcanically enhanced sulfate aerosol on stratospheric ozone is of particular importance as the artificial injection of sulfur into the stratosphere is being discussed as a way to mitigate global warming (Crutzen, 2006; Rasch et al., 2008); such a course of action is predicted to have detrimental effects on polar ozone (e.g., Tilmes et al., 2008a, 2009). Model studies should be conducted using state-of-the-art three-dimensional chemical transport models that allow the temperature and latitude excursions of air parcels to be described, which are important for the details of heterogeneous chlorine activation, chlorine deactivation, and catalytic ozone loss.

\section{Conclusions}

The temperature threshold $T_{\mathrm{ACL}}$ for activation of chlorine in the polar stratosphere is a useful quantity for diagnosing and parameterising the onset of chlorine activation and subsequent polar ozone loss. It is a coincidence, however, that under typical stratospheric conditions at $\sim 20 \mathrm{~km}$ a temperature of $195 \mathrm{~K}$ (or $T_{\mathrm{NAT}}$ ) provides an approximate estimate for the threshold that describes both the onset of heterogeneous chlorine activation and PSC occurrence. This coincidence does not imply that the same processes control the microphysics of PSC formation and heterogeneous chemistry, nor does it imply that chlorine activation occurs at $T_{\mathrm{NAT}}$ under different conditions. $T_{\mathrm{NAT}}$ is a microphysical parameter that is essential for understanding where NAT PSCs may form or exist and where denitrification is likely. However, for chemical applications, $T_{\mathrm{NAT}}$ misrepresents the processes controlling the threshold for the onset of chlorine activation.

We suggest that, as a metric for the onset of polar chlorine activation and the resulting chemical ozone loss, $T_{\mathrm{NAT}}$ should no longer be used. It is important that, in models designed to describe the full heterogeneous chemistry, liquid phase reactions are included in detail and that NAT formation and NAT surface area densities are realistically represented. Furthermore, the temperature dependence of heterogeneous reaction probabilities $\gamma$ should be implemented in models in a realistic manner.

It is not possible to replace a detailed model calculation by considering simple temperature proxies for chlorine activation. However, based on reaction rates on cold binary aerosol, we have derived here a temperature threshold for polar chlorine activation $T_{\mathrm{ACL}}$, which provides a more accurate description of the temperature conditions necessary for chlorine activation and ozone loss in the polar stratosphere than $T_{\mathrm{NAT}}$. There are applications where replacing $T_{\mathrm{NAT}}$ with $T_{\mathrm{ACL}}$ will provide a simple, practical way of achieving a more processoriented basis for ozone loss metrics or parameterisations. This will allow improvements such as more accurate modelmeasurement intercomparisons (especially when accounting for $\mathrm{HNO}_{3}$ variations) and an integrated treatment of volcanic aerosol effects. Assessments based on $T_{\mathrm{NAT}}$ will, for example, underestimate the ramifications of artificially enhancing stratospheric aerosol, which has been proposed as a climate modification to mitigate global warming (Crutzen, 2006; Tilmes et al., 2008a; Rasch et al., 2008). Similarly, using $T_{\mathrm{ACL}}$ in place of $T_{\mathrm{NAT}}$ results in a stronger dependence of chlorine activation on stratospheric water vapour (KirkDavidoff et al., 1999; Feck et al., 2008; Vogel et al., 2011).

Although $T_{\mathrm{NAT}}$ is inappropriate for describing chlorine activation, it remains a useful parameter for assessing where PSCs are likely to occur. $T_{\mathrm{NAT}}$ is the highest temperature at which NAT PSCs can possibly exist; other $\mathrm{HNO}_{3}$-containing PSCs, for example STS, occur at relatively constant temperature offsets relative to $T_{\mathrm{NAT}}$. $T_{\mathrm{NAT}}$ may also be relevant for processes that are controlled by PSC microphysics. Denitrification, in particular, will be controlled by exposure to temperatures below $T_{\mathrm{NAT}}$, introducing a connection between $T_{\text {NAT }}$ and ozone loss. However, denitrification can only 
supplement the ozone loss caused by chlorine activation, and therefore is a secondary influence on ozone.

In summary, the onset of heterogeneous chlorine activation leading to polar ozone depletion is dominated by reactions on liquid, cold binary particles, which do not cause substantial uptake of $\mathrm{HNO}_{3}$ from the gas phase (less than one percent). As a metric for the onset of heterogeneous chlorine activation, $T_{\mathrm{ACL}}$ is a more appropriate parameter than $T_{\mathrm{NAT}}$ and will allow a more accurate assessment of the response of the polar stratosphere to future climate change.

Acknowledgements. We are grateful to Dave Fahey, Jens-Uwe Grooß, Thomas Peter, Bob Portmann, Ross Salawitch, Susan Solomon, Simone Tilmes, and Tobias Wegner for very helpful discussions and for constructive critical comments. We thank Thomas Peter, Ross Salawitch, Susan Solomon and a number of anonymous referees for their thoughtful reviews. We also thank Tobias Wegner very much for providing Figs. 1 and 2. This research was supported in part by NASA's Earth Science Enterprise through the Atmospheric Chemistry and Modeling Analysis Program, NRA-02-OES02 and by the European Union EU-FP7-226365-RECONCILE grant. We are grateful to the United Kingdom Met Office for providing meteorological analyses.

Topical Editor C. Jacobi thanks R. J. Salawitch and one anonymous referee for their help in evaluating this paper.

\section{References}

Abbatt, J. P. D. and Molina, M. J.: Heterogeneous interactions of $\mathrm{ClONO}_{2}$ and $\mathrm{HCl}$ on nitric acid trihydrate at $202 \mathrm{~K}$, J. Phys. Chem., 96, 7674-7679, 1992.

Bauman, J. J., Russel, P. B., Geller, M. A., and Hamill, P.: A stratospheric aerosol climatology from SAGE II and CLAES measurements: 2. Results and comparisons, 1984-1999, J. Geophys. Res., 108, 4383, doi:10.1029/2002JD002993, 2003.

Benson, C. M., Drdla, K., Nedoluha, G. E., Shettle, E. P., Hoppel, K. W., and Bevilacqua, R. M.: Microphysical modeling of southern polar dehydration during the 1998 winter and comparison with POAM III observations, J. Geophys. Res., 111, D07201, doi:10.1029/2005JD006506, 2006.

Biele, J., Tsias, A., Luo, B. P., Carslaw, K. S., Neuber, R., Beyerle, G., and Peter, T.: Nonequilibrium coexistence of solid and liquid particles in Arctic stratospheric clouds, J. Geophys. Res., 106, 22991-23007, 2001.

Blum, U., Fricke, K. H., Müller, K. P., Siebert, J., and Baumgarten, G.: Long-term lidar observations of polar stratospheric clouds at Esrange in northern Sweden, Tellus B, 57, 412-422, 2005.

Brasseur, G. and Solomon, S.: Aeronomy of the Middle Atmosphere: Chemistry and Physics of the Stratosphere and Mesosphere, 3rd Edn., Springer, Heidelberg, Germany, 2005.

Buchholz, J.: Simulations of physics and chemistry of polar stratospheric clouds with a general circulation model, Ph.D. thesis, University of Mainz, Germany, http://nbn-resolving.de/urn/ resolver.pl?urn=urn:nbn:de:hebis:77-8187, 2005.

Carslaw, K. S. and Peter, T.: Uncertainties in reactive uptake coefficients for solid stratospheric particles -1 . Surface chemistry, Geophys. Res. Lett., 24, 1743-1746, 1997.
Carslaw, K. S., Luo, B. P., Clegg, S. L., Peter, T., Brimblecombe, P., and Crutzen, P. J.: Stratospheric aerosol growth and $\mathrm{HNO}_{3}$ gas phase depletion from coupled $\mathrm{HNO}_{3}$ and water uptake by liquid particles, Geophys. Res. Lett., 21, 2479-2482, doi:10.1029/94GL02799, 1994.

Carslaw, K. S., Luo, B. P., and Peter, T.: An analytical expression for the composition of aqueous $\mathrm{HNO}_{3}-\mathrm{H}_{2} \mathrm{SO}_{4}-\mathrm{H}_{2} \mathrm{O}$ stratospheric aerosols including gas phase removal of $\mathrm{HNO}_{3}$, Geophys. Res. Lett., 22, 1877-1880, doi:10.1029/95GL01668, 1995.

Carslaw, K. S., Peter, T., and Clegg, S. L.: Modeling the composition of liquid stratospheric aerosols, Rev. Geophys., 35, 125-154, 1997a.

Carslaw, K. S., Peter, T., and Müller, R.: Uncertainties in reactive uptake coefficients for solid stratospheric particles -2 . effect on ozone depletion, Geophys. Res. Lett., 24, 1747-1750, 1997b.

Chipperfield, M. P., Cariolle, D., and Simon, P.: A 3D transport model study of chlorine activation during EASOE, Geophys. Res. Lett., 21, 1467-1470, doi:10.1029/93GL01679, 1994.

Chipperfield, M. P., Feng, W., and Rex, M.: Arctic ozone loss and climate sensitivity: Updated three-dimensional model study, Geophys. Res. Lett., 32, L11813, doi:10.1029/2005GL022674, 2005.

Cox, R. A., MacKenzie, A. R., Müller, R. H., Peter, T., and Crutzen, P. J.: Activation of stratospheric chlorine by reactions in liquid sulphuric acid, Geophys. Res. Lett., 21, 1439-1442, 1994.

Crutzen, P. J.: Albedo enhancements by stratospheric sulfur injections: a contribution to resolve a policy dilemma? An Editorial Essay, Clim. Change, 77, 211-219, 2006.

Crutzen, P. J., Müller, R., Brühl, C., and Peter, T.: On the potential importance of the gas phase reaction $\mathrm{CH}_{3} \mathrm{O}_{2}+\mathrm{ClO} \rightarrow$ $\mathrm{ClOO}+\mathrm{CH}_{3} \mathrm{O}$ and the heterogeneous reaction $\mathrm{HOCl}+\mathrm{HCl} \rightarrow$ $\mathrm{H}_{2} \mathrm{O}+\mathrm{Cl}_{2}$ in "ozone hole" chemistry, Geophys. Res. Lett., 19, 1113-1116, doi:10.1029/92GL01172, 1992.

Dameris, M., Peter, T., Schmidt, U., and Zellner, R.: Das Ozonloch und seine Ursachen, Chem. Unserer Zeit, 41, 152-168, doi:10.1002/ciuz.200700418, 2007.

Davies, S., Chipperfield, M. P., Carslaw, K. S., Sinnhuber, B.-M., Anderson, J. G., Stimpfle, R. M., Wilmouth, D. M., Fahey, D. W., Popp, P. J., Richard, E. C., von der Gathen, P., Jost, H., and Webster, C. R.: Modeling the effect of denitrification on Arctic ozone depletion during winter 1999/2000, J. Geophys. Res., 107, 8322, doi:10.1029/2001JD000445, 2002.

Davies, S., Mann, G. W., Carslaw, K. S., Chipperfield, M. P., Kettleborough, J. A., Santee, M. L., Oelhaf, H., Wetzel, G., Sasano, Y., and Sugita, T.: 3-D microphysical model studies of Arctic denitrification: comparison with observations, Atmos. Chem. Phys., 5, 3093-3109, doi:10.5194/acp-5-3093-2005, 2005.

Del Negro, L. A., Fahey, D. W., Donnelly, S. G., Gao, R. S., Keim, E. R., Wamsley, R. C., Woodbridge, E. L., Dye, J. E., Baumgardner, D., Gandrud, B. W., Wilson, J. C., Jonsson, H. H., Loewenstein, M., Podolske, J. R., Webster, C. R., May, R. D., Worsnop, D. R., Tabazadeh, A., Tolbert, M. A., Kelly, K. K., and Chan, K. R.: Evaluating the role of NAT, NAD, and liquid $\mathrm{H}_{2} \mathrm{SO}_{4} / \mathrm{H}_{2} \mathrm{O} / \mathrm{HNO}_{3}$ solutions in Antarctic polar stratospheric cloud aerosol: Observations and implications,, J. Geophys. Res., 102, 13255-13282, 1997.

Deshler, T., Bryan, B. J., Hofmann, D. J., and Nardi, B.: Correlation between ozone loss and volcanic aerosol at altitudes below $14 \mathrm{~km}$ over McMurdo Station, Antarctica, Geophys. Res. Lett., 
21, 2931-2934, 1996.

Douglass, A. R., Schoeberl, M. R., Stolarski, R. S., Waters, J. W., Russell III, J. M., Roche, A. E., and Massie, S. T.: Interhemispheric differences in springtime production of $\mathrm{HCl}$ and $\mathrm{ClONO}_{2}$ in the polar vortices, J. Geophys. Res., 100, 13967-13978, 1995.

Douglass, A. R., Stolarski, R. S., Strahan, S. E., and Polansky, B. C.: Sensitivity of Arctic ozone loss to polar stratospheric cloud volume and chlorine and bromine loading in a chemistry and transport model, Geophys. Res. Lett., 33, L17809, doi:10.1029/2006GL026492, 2006.

Drdla, K.: Temperature thresholds for polar stratospheric ozone, Eos Trans. AGU, 86, Fall Meet. Suppl., Abstract A31D-03, 2005.

Drdla, K.: Re-examining polar ozone loss: Do polar stratospheric clouds really control chlorine activation?, Geophys. Res. Abstracts, 8, 09979, sRef-ID: 1607-7962/gra/EGU06-A-09979, 2006.

Drdla, K. and Müller, R.: Temperature thresholds for polar stratospheric ozone loss, Atmos. Chem. Phys. Discuss., 10, $28687-$ 28720, doi:10.5194/acpd-10-28687-2010, 2010.

Drdla, K. and Schoeberl, M. R.: Microphysical modeling of the 1999-2000 Arctic winter 2. Chlorine activation and ozone depletion, J. Geophys. Res., 107, 8319, doi:10.1029/2001JD001159, 2002

Drdla, K., Schoeberl, M. R., and Browell, E. V.: Microphysical modeling of the 1999-2000 Arctic winter 1. Polar stratospheric clouds, denitrification, and dehydration, J. Geophys. Res., 107, 8312, doi:10.1029/2001JD000782, 2002.

Dye, J., Gandrud, B., Baumgardner, D., Chan, K., Ferry, G., Loewenstein, M., Kelly, K., and Wilson, J.: Observed particle evolution in the polar stratospheric cloud of January 24, 1989, Geophys. Res. Lett., 17, 413-416, 1990.

Dye, J. E., Baumgardner, D., Gandrud, B. W., Kawa, S. R., Kelly, K. K., Loewenstein, M., Ferry, G. V., Chan, K. R., and Gary, B. L.: Particle size distributions in Arctic polar stratospheric clouds, growth and freezing of sulfuric acid droplets and implications for cloud formation, J. Geophys. Res., 97, 8015-8034, 1992.

Elrod, M. J., Koch, R. E., Kim, J. E., and Molina, M.: HCl vapour pressures and reaction probabilities for $\mathrm{ClONO}_{2}+\mathrm{HCl}$ on liquid $\mathrm{H}_{2} \mathrm{SO}_{4}-\mathrm{HNO}_{3}-\mathrm{HCl}-\mathrm{H}_{2} \mathrm{O}$ solutions, Faraday Discuss., 100, 269 278,1995

Engel, A., Müller, R., Schmidt, U., Carslaw, K. S., and Stachnik, R. A.: Indications of heterogeneous chlorine activation on moderately cold aerosol based on chlorine observations in the Arctic stratosphere, Atmos. Environ., 34, 4283-4289, 2000.

Eskes, H., van Velthoven, P., Valks, P., and Kelder, H.: Assimilation of GOME total ozone satellite observations in a threedimensional tracer-transport model, Q. J. Roy. Meteor. Soc., 129, 1663-1682, 2003.

Eskes, H. J., Segers, A., and van Velthoven, P.: Ozone forecasts of the stratospheric polar vortex splitting event in September 2002, J. Atmos. Sci., 62, 812-821, 2005.

Eyring, V., Waugh, D. W., Bodeker, G. E., Cordero, E., Akiyoshi, H., Austin, J., Beagley, S. R., Boville, B. A., Braesicke, P., Brühl, C., Butchart, N., Chipperfield, M. P., Dameris, M., Deckert, R., Deushi, M., Frith, S. M., Garcia, R. R., Gettelman, A., Giorgetta, M. A., Kinnison, D. E., Mancini, E., Manzini, E., Marsh, D. R., Matthes, S., Nagashima, T., Newman, P. A., Nielsen, J. E., Pawson, S., Pitari, G., Plummer, D. A., Rozanov, E., Schraner, M.,
Scinocca, J. F., Semeniuk, K., Shepherd, T. G., Shibata, K., Steil, B., Stolarski, R. S., Tian, W., and Yoshiki, M.: Multimodel projections of stratospheric ozone in the 21st century, J. Geophys. Res., 112, D16303, doi:10.1029/2006JD008332, 2007.

Eyring, V., Sheperd, T. G., and Waugh, D. W. (Eds.): SPARC report on the evaluation of chemistry-climate models, SPARC Rep. No. 5, WRCP-132, WMO-TD No. 1526, World Meteorol. Organ., Geneva, 2010.

Fahey, D. W., Gao, R. S., Carslaw, K. S., Kettleborough, J., Popp, P. J., Northway, M. J., Holecek, J. C., Ciciora, S. C., McLaughlin, R. J., Thompson, T. L., Winkler, R. H., Baumgardner, D. G., Gandrud, B., Wennberg, P. O., Dhaniyala, S., McKinley, K., Peter, T., Salawitch, R. J., Bui, T. P., Elkins, J. W., Webster, C. R., Atlas, E. L., Jost, H., Wilson, J. C., Herman, R. L., Kleinböhl, A., and von König, M.: The detection of large $\mathrm{HNO}_{3}$-containing particles in the winter Arctic stratosphere, Science, 291, 1026-1031, 2001.

Farman, J. C., Gardiner, B. G., and Shanklin, J. D.: Large losses of total ozone in Antarctica reveal seasonal $\mathrm{ClO}_{\mathrm{x}} / \mathrm{NO}_{\mathrm{x}}$ interaction, Nature, 315, 207-210, 1985.

Feck, T., Grooß, J.-U., and Riese, M.: Sensitivity of Arctic ozone loss to stratospheric $\mathrm{H}_{2} \mathrm{O}$, Geophys. Res. Lett., 35, L01803, doi:10.1029/2007GL031334, 2008.

Fox, L. E., Wofsy, S. C., Worsnop, D. R., and Zahniser, M. S.: Metastable phases in polar stratospheric aerosols, Science, 267, 351-355, doi:10.1126/science.267.5196.351, 1995.

Fueglistaler, S., Luo, B. P., Voigt, C., Carslaw, K. S., and Peter, Th.: NAT-rock formation by mother clouds: a microphysical model study, Atmos. Chem. Phys., 2, 93-98, doi:10.5194/acp-293-2002, 2002.

Garcia, R. R., Marsh, D. R., Kinnison, D. E., Boville, B. A., and Sassi, F.: Simulation of secular trends in the middle atmosphere, 1950-2003, J. Geophys. Res., 112, D09301, doi:10.1029/2006JD007485, 2007.

Geer, A. J., Lahoz, W. A., Bekki, S., Bormann, N., Errera, Q., Eskes, H. J., Fonteyn, D., Jackson, D. R., Juckes, M. N., Massart, S., Peuch, V.-H., Rharmili, S., and Segers, A.: The ASSET intercomparison of ozone analyses: method and first results, Atmos. Chem. Phys., 6, 5445-5474, doi:10.5194/acp-6-5445-2006, 2006.

Grooß, J.-U., Pierce, R. B., Crutzen, P. J., Grose, W. L., and Russell III, J. M.: Re-formation of chlorine reservoirs in southern hemisphere polar spring, J. Geophys. Res., 102, 13141-13152, doi:10.1029/96JD03505, 1997.

Grooß, J.-U., Günther, G., Müller, R., Konopka, P., Bausch, S., Schlager, H., Voigt, C., Volk, C. M., and Toon, G. C.: Simulation of denitrification and ozone loss for the Arctic winter 2002/2003, Atmos. Chem. Phys., 5, 1437-1448, doi:10.5194/acp-5-14372005, 2005.

Grooß, J.-U., Brautzsch, K., Pommrich, R., Solomon, S., and Müller, R.: Stratospheric ozone chemistry in the Antarctic: what determines the lowest ozone values reached and their recovery?, Atmos. Chem. Phys., 11, 12217-12226, doi:10.5194/acp11-12217-2011, 2011.

Hadjinicolaou, P., Pyle, J. A., Chipperfield, M. P., and Kettleborough, J. A.: Effect of interannual meteorological variability on mid-latitude $\mathrm{O}_{3}$, Geophys. Res. Lett., 24, 2993-2996, 1997.

Hanisco, T. F., Smith, J. B., Stimpfle, R. M., Wilmouth, D. M., Perkins, K. K., Spackman, J. R., Anderson, J. G., Baumgardner, 
D., Gandrud, B., Webster, C. R., Dhaniyala, S., McKinney, K. A., and Bui, T. P.: Quantifying the rate of heterogeneous processing in the Arctic polar vortex with in situ observations of $\mathrm{OH}, \mathrm{J}$. Geophys. Res., 107, 8278, doi:10.1029/2001JD000425, 2002.

Hanson, D. R. and Mauersberger, K.: Laboratory studies of the nitric acid trihydrate: Implications for the south polar stratosphere, Geophys. Res. Lett., 15, 855-858, doi:10.1029/GL015i013p01507, 1988.

Hanson, D. R. and Ravishankara, A. R.: Reaction of $\mathrm{ClONO}_{2}$ with $\mathrm{HCl}$ on NAT, NAD, and frozen sulfuric acid and hydrolysis of $\mathrm{N}_{2} \mathrm{O}_{5}$ and $\mathrm{ClONO}_{2}$ on frozen sulfuric acid, J. Geophys. Res., 98, 22931-22936, 1993.

Hanson, D. R., Ravishankara, A. R., and Solomon, S.: Heterogeneous reactions in sulfuric acid aerosols: A framework for model calculations, J. Geophys. Res., 99, 3615-3629, 1994.

Henderson, G. S., Evans, W. F. J., and McConnell, J. C.: Effects of initial active chlorine concentrations on the Antarctic ozone spring depletion, J. Geophys. Res., 95, 1899-1908, doi:10.1029/JD095iD02p01899, 1990.

Hitchcock, P., Shepherd, T. G., and McLandress, C.: Past and future conditions for polar stratospheric cloud formation simulated by the Canadian Middle Atmosphere Model, Atmos. Chem. Phys., 9, 483-495, doi:10.5194/acp-9-483-2009, 2009.

Hofmann, D. and Oltmans, S.: Anomalous Antarctic ozone during 1992: Evidence for Pinatubo volcanic aerosol effects, J. Geophys. Res., 98, 18555-18561, 1993.

Hofmann, D. J. and Solomon, S.: Ozone destruction through heterogeneous chemistry following the eruption of El Chichón, J. Geophys. Res., 94, 5029-5041, 1989.

Hofmann, D. J., Deshler, T. L., Aimedieu, P., Matthews, W. A., Johnston, P. V., Kondo, Y., Byrne, W. R. S. G. J., and Benbrook, J. R.: Stratospheric clouds and ozone depletion in the Arctic during January 1989, Nature, 340, 117-121, 1989.

Höpfner, M., Pitts, M. C., and Poole, L. R.: Comparison between CALIPSO and MIPAS observations of polar stratospheric clouds, J. Geophys. Res., 114, D00H05, doi:10.1029/2009JD012114, 2009.

IPCC/TEAP: Special Report on Safeguarding the Ozone Layer and the Global Climate System: Issues Related to Hydrofluorocarbons and Perfluorocarbons. Prepared by Working Groups I and III of the Intergovernmental Panel on Climate Change, and the Technical and Economic Assessment Panel, Cambridge University Press, Cambridge, United Kingdom, and New York, NY, USA, edited by: Metz, B., Kuijpers, L., Solomon, S., Andersen, S. O., Davidson, O., Pons, J., de Jager, D., Kestin, T., Manning, M., and Meyer, L., 2005.

Jaeglé, L., Webster, C. R., May, R. D., Scott, D. C., Stimpfle, R. M., Kohn, D. W., Wennberg, P. O., Hanisco, T. F., Cohen, R. C., Proffitt, M. H., Kelly, K. K., Elkins, J., Baumgardner, D., Dye, J. E., Wilson, J. C., Pueschel, R. F., Chan, K. R., Salawitch, R. J., Tuck, A. F., Hovde, S. J., and Yung, Y. L.: Evolution and stoichiometry of heterogeneous processing in the Antarctic stratosphere, J. Geophys. Res., 102, 13235-13253, doi:10.1029/97JD00935, 1997.

Jones, A. E. and Shanklin, J. D.: Continued decline of total ozone over Halley, Antarctica, since 1985, Nature, 376, 409-411, 1995.

Jones, R. L., McKenna, D. S., Poole, L. R., and Solomon, S.: On the influence of polar stratospheric cloud formation on chemical composition during the 1988/89 arctic winter, Geophys. Res.
Lett., 17, 545-548, 1990a.

Jones, R. L., Solomon, S., McKenna, D. S., Poole, L. R., Brune, W. H., Toohey, D. W., Anderson, J. G., and Fahey, D. W.: The polar stratospheric cloud event of January, 24 Part 2, Photochemistry, Geophys. Res. Lett., 17, 541-544, 1990 b.

Kawa, S. R., Newman, P. A., Lait, L. R., Schoeberl, M. R., Stimpfle, R. M., Kohn, D. W., Webster, C. R., May, R. D., Baumgardner, D., Dye, J. E., Wilson, J. C., Chan, K. R., and Loewenstein, M.: Activation of chlorine in sulfate aerosol as inferred from aircraft observations, J. Geophys. Res., 102, 3921-3933, 1997.

Kawa, S. R., Stolarski, R. S., Newman, P. A., Douglass, A. R., Rex, M., Hofmann, D. J., Santee, M. L., and Frieler, K.: Sensitivity of polar stratospheric ozone loss to uncertainties in chemical reaction kinetics, Atmos. Chem. Phys., 9, 8651-8660, doi:10.5194/acp-9-8651-2009, 2009.

Kettleborough, J. A., Carver, G. D., Lary, D. J., Pyle, J. A., and Scott, P. A.: Three dimensional modelling of chlorine activation in the Arctic stratosphere, Geophys. Res. Lett., 21, 1471-1474, doi:10.1029/93GL03048, 1994.

Khosrawi, F., Urban, J., Pitts, M. C., Voelger, P., Achtert, P., Kaphlanov, M., Santee, M. L., Manney, G. L., Murtagh, D., and Fricke, K.-H.: Denitrification and polar stratospheric cloud formation during the Arctic winter 2009/2010, Atmos. Chem. Phys., 11, 8471-8487, doi:10.5194/acp-11-8471-2011, 2011.

Kiesewetter, G., Sinnhuber, B.-M., Vountas, M., Weber, M., and Burrows, J. P.: A long-term stratospheric ozone data set from assimilation of satellite observations: Highlatitude ozone anomalies, J. Geophys. Res., 115, D10307, doi:10.1029/2009JD013362, 2010.

Kim, Y., Choi, W., Lee, K., Park, J. H., Massie, S. T., Sasano, Y., Nakajima, H., and Yokota, T.: Polar stratospheric clouds observed by the ILAS-II in the Antarctic region: Dual compositions and variation of compositions during June to August of 2003, J. Geophys. Res., 111, D13S90, doi:10.1029/2005JD006445, 2006.

Kirk-Davidoff, D. B., Hintsa, E. J., Anderson, J. G., and Keith, D. W.: The effect of climate change on ozone depletion through changes in stratospheric water vapour, Nature, 402, 399-401, doi:10.1038/46521, 1999.

Knudsen, B. M., Harris, N. R. P., Andersen, S. B., Christiansen, B., Larsen, N., Rex, M., and Naujokat, B.: Extrapolating future Arctic ozone losses, Atmos. Chem. Phys., 4, 1849-1856, doi:10.5194/acp-4-1849-2004, 2004.

Krämer, M., Müller, R. I., Bovensmann, H., Burrows, J., Brinkmann, J., Röth, E. P., Grooß, J. U., Müller, R. O., Woyke, T. H., Ruhnke, R., Günther, G., Hendricks, J., Lippert, E., Carslaw, K. S., Peter, T., Zieger, A., Brühl, C. H., Steil, B., Lehmann, R., and McKenna, D. S.: Intercomparison of stratospheric chemistry models under polar vortex conditions, J. Atmos. Chem., 45, 51-77, doi:10.1023/A:1024056026432, 2003.

Kühl, S., Dörnbrack, A., Wilms-Grabe, W., Sinnhuber, B.-M., Platt, U., and Wagner, T.: Observational evidence of rapid chlorine activation by mountain waves above northern Scandinavia, J. Geophys. Res., 109, D22309, doi:10.1029/2004JD004797, 2004.

Lambert, A., Santee, M. L., Wu, D. L., and Chae, J. H.: A-train CALIOP and MLS observations of early winter Antarctic polar stratospheric clouds and nitric acid in 2008, Atmos. Chem. Phys., 12, 2899-2931, doi:10.5194/acp-12-2899-2012, 2012. 
Larsen, N., Knudsen, B. M., Svendsen, S. H., Deshler, T., Rosen, J. M., Kivi, R., Weisser, C., Schreiner, J., Mauerberger, K., Cairo, F., Ovarlez, J., Oelhaf, H., and Spang, R.: Formation of solid particles in synoptic-scale Arctic PSCs in early winter 2002/2003, Atmos. Chem. Phys., 4, 2001-2013, doi:10.5194/acp-4-20012004, 2004.

Lowe, D. and MacKenzie, A. R.: Polar stratospheric cloud microphysics and chemistry, J. Atmos. Sol.-Terr. Phy., 70, 13-40, doi:10.1016/j.jastp.2007.09.011, 2008.

Manney, G. L., Froidevaux, L., Santee, M. L., Livesey, N. J., Sabutis, J. L., and Waters, J. W.: Variability of ozone loss during Arctic winter (1991 to 2000) estimated from UARS Microwave Limb Sounder measurements, J. Geophys. Res., 108, 4149, doi:10.1029/2002JD002634, 2003.

Manney, G. L., Santee, M. L., Rex, M., Livesey, N. J., Pitts, M. C., Veefkind, P., Nash, E. R., Wohltmann, I., Lehmann, R., Froidevaux, L., Poole, L. R., Schoeberl, M. R., Haffner, D. P., Davies, J., Dorokhov, V., Gernandt, H., Johnson, B., Kivi, R., Kyrö, E., Larsen, N., Levelt, P. F., Makshtas, A., McElroy, C. T., Nakajima, H., Parrondo, M. C., Tarasick, D. W., von der Gathen, P., Walker, K. A., and Zinoviev, N. S.: Unprecedented Arctic ozone loss in 2011, Nature, 478, 469-475, doi:10.1038/nature10556, 2011.

McElroy, M. B., Salawitch, R. J., Wofsy, S. C., and Logan, J. A.: Antarctic ozone: Reductions due to synergistic interactions of chlorine and bromine, Nature, 321, 759-762, 1986.

Molina, L. T. and Molina, M. J.: Production of $\mathrm{Cl}_{2} \mathrm{O}_{2}$ from the selfreaction of the $\mathrm{ClO}$ radical, J. Phys. Chem., 91, 433-436, 1987.

Morgenstern, O., Giorgetta, M. A., Shibata, K., Eyring, V., Waugh, D. W., Shepherd, T. G., Akiyoshi, H., Austin, J., Baumgaertner, A. J. G., Bekki, S., Braesicke, P., Brühl, C., Chipperfield, M. P., Cugnet, D., Dameris, M., Dhomse, S., Frith, S. M., Garny, H., Gettelman, A., Hardiman, S. C., Hegglin, M. I., Jöckel, P., Kinnison, D. E., Lamarque, J., Mancini, E., Manzini, E., Marchand, M., Michou, M., Nakamura, T., Nielsen, J. E., Olivié, D., Pitari, G., Plummer, D. A., Rozanov, E., Scinocca, J. F., Smale, D., Teyssèdre, H., Toohey, M., Tian, W., and Yamashita, Y.: Review of the formulation of present-generation stratospheric chemistryclimate models and associated external forcings, J. Geophys. Res., 115, D00M02, doi:10.1029/2009JD013728, 2010.

Müller, R., Peter, T., Crutzen, P. J., Oelhaf, H., Adrian, G. P., v. Clarmann, T., Wegner, A., Schmidt, U., and Lary, D.: Chlorine chemistry and the potential for ozone depletion in the Arctic stratosphere in the winter of 1991/92, Geophys. Res. Lett., 21, 1427-1430, 1994.

Müller, R., Crutzen, P. J., Grooß, J.-U., Brühl, C., Russell III, J. M., and Tuck, A. F.: Chlorine activation and ozone depletion in the Arctic vortex: Observations by the Halogen Occultation Experiment on the Upper Atmosphere Research Satellite, J. Geophys. Res., 101, 12531-12554, 1996.

Müller, R., Tilmes, S., Grooß, J.-U., McKenna, D. S., Müller, M., Schmidt, U., Toon, G. C., Stachnik, R. A., Margitan, J. J., Elkins, J. W., Arvelius, J., and Russell III, J. M.: Chlorine activation and chemical ozone loss deduced from HALOE and balloon measurements in the Arctic during the winter of 1999-2000, J. Geophys. Res., 107, 8302, doi:10.1029/2001JD001423, 2002.

Northway, M. J., Gao, R. S., Popp, P. J., Holecek, J. C., Fahey, D. W., Carslaw, K. S., Tolbert, M. A., Lait, L. R., Dhaniyala, S., Flagan, R. C., Wennberg, P. O., Mahoney, M. J., Herman, R. L., Toon, G. C., and Bui, T. P.: An analysis of large
$\mathrm{HNO}_{3}$-containing particles sampled in the Arctic stratosphere during the winter of 1999/2000, J. Geophys. Res., 107, 8298, doi:10.1029/2001JD001079, 2002.

Peter, T.: Microphysics and heterogeneous chemistry of polar stratospheric clouds, Ann. Rev. Phys. Chem., 48, 785-822, 1997.

Peter, T. and Grooß, J.-U.: Polar Stratospheric Clouds and Sulfate Aerosol Particles: Microphysics, Denitrification and Heterogeneous Chemistry, in: Stratospheric Ozone Depletion and Climate Change, edited by: Müller, R., Royal Society of Chemistry, 108144, doi:10.1039/9781849733182-00108, ISBN: 978-1-84973002-0, 2012.

Pitari, G., Mancini, E., Rizi, V., and Shindell, D. T.: Impact of future climate and emission changes on stratospheric aerosols and ozone, J. Atmos. Sci., 59, 414-440, 2002.

Pitts, M. C., Thomason, L. W., Poole, L. R., and Winker, D. M.: Characterization of Polar Stratospheric Clouds with spaceborne lidar: CALIPSO and the 2006 Antarctic season, Atmos. Chem. Phys., 7, 5207-5228, doi:10.5194/acp-7-5207-2007, 2007.

Pitts, M. C., Poole, L. R., Dörnbrack, A., and Thomason, L. W.: The 2009-2010 Arctic polar stratospheric cloud season: a CALIPSO perspective, Atmos. Chem. Phys., 11, 2161-2177, doi:10.5194/acp-11-2161-2011, 2011.

Pitts, M. C., Poole, L. R., and Thomason, L. W.: CALIPSO polar stratospheric cloud observations: second-generation detection algorithm and composition discrimination, Atmos. Chem. Phys., 9, 7577-7589, doi:10.5194/acp-9-7577-2009, 2009.

Portmann, R. W., Solomon, S., Garcia, R. R., Thomason, L. W., Poole, L. R., and McCormick, M. P.: Role of aerosol variations in anthropogenic ozone depletion in the polar regions, J. Geophys. Res., 101, 22991-23006, 1996.

Prather, M. J.: More rapid ozone depletion through the reaction of $\mathrm{HOCl}$ with $\mathrm{HCl}$ on polar stratospheric clouds, Nature, 355, 534537, 1992.

Rasch, P. J., Tilmes, S., Turco, R. P., Robock, A., Oman, L., Stenchikov, G. L., and Garcia, R. R.: An overview of geoengineering of climate using stratospheric sulphate aerosols, Proc. R. Soc. London A, 366, 4007-4037, doi:10.1098/rsta.2008.0131, 2008.

Ravishankara, A. R. and Hanson, D. R.: Differences in the reactivity of Type I polar stratospheric clouds depending on their phase, J. Geophys. Res., 101, 3885-3890, 1996.

Rex, M., Salawitch, R. J., von der Gathen, P., Harris, N. R. P., Chipperfield, M. P., and Naujokat, B.: Arctic ozone loss and climate change, Geophys. Res. Lett., 31, L04116, doi:10.1029/2003GL018844, 2004.

Rex, M., Salawitch, R. J., Deckelmann, H., von der Gathen, P., Harris, N. R. P., Chipperfield, M. P., Naujokat, B., Reimer, E., Allaart, M., Andersen, S. B., Bevilacqua, R., Braathen, G. O., Claude, H., Davies, J., De Backer, H., Dier, H., Dorokov, V., Fast, H., Gerding, M., Godin-Beekmann, S., Hoppel, K., Johnson, B., Kyrö, E., Litynska, Z., Moore, D., Nakane, H., Parrondo, M. C., Risley Jr., A. D., Skrivankova, P., Stübi, R., Viatte, P., Yushkov, V., and Zerefos, C.: Arctic winter 2005: Implications for stratospheric ozone loss and climate change, Geophys. Res. Lett., 33, L23808, doi:10.1029/2006GL026731, 2006.

Salawitch, R. J., Wofsy, S. C., and McElroy, M. B.: Influence of polar stratospheric clouds on the depletion of Antarctic ozone, Geophys. Res. Lett., 15, 871-874, 1988. 
Salawitch, R. J., Gobbi, G. P., Wofsy, S. C., and McElroy, M. B.: Denitrification in the Antarctic stratosphere, Nature, 339, 525$527,1989$.

Salawitch, R. J., Margitan, J. J., Sen, B., Toon, G. C., Osterman, G. B., Rex, M., Elkins, J. W., Ray, E. A., Moore, F. L., Hurst, D. F., Romashkin, P. A., Bevilacqua, R. M., Hoppel, K., Richard, E. C., and Bui, T. P.: Chemical loss of ozone during the Arctic winter of 1999-2000: an analysis based on balloon-borne observations, J. Geophys. Res., 107, 8269, doi:10.1029/2001JD000620, 2002.

Sander, S. P., Friedl, R. R., Golden, D. M., Kurylo, M. J., Huie, R. E., Orkin, V. L., Moortgat, G. K., Wine, P. H., Ravishankara, A. R., Kolb, C. E., Molina, M. J., and Finlayson-Pitts, B. J.: Evaluation number 15, Chemical kinetics and photochemical data for use in atmospheric studies, NASA Panel for Data Evaluation, JPL Publication 06-2, Jet Propulsion Laboratory, California Insitute of Technology, Pasadena, California, 2006.

Sander, S. P., Abbatt, J., Barker, J. R., Burkholder, J. B., Friedl, R. R., Golden, D. M., Huie, R. E., Kolb, C. E., Kurylo, M. J., Moortgat, G. K., Orkin, V. L., and Wine, P. H.: Evaluation No. 17, JPL Publication 10-6, Chemical Kinetics and Photochemical Data for Use in Atmospheric Studies, Jet Propulsion Laboratory, Pasadena, http://jpldataeval.jpl.nasa.gov, 2011.

Santee, M. L., Manney, G. L., Froidevaux, L., Zurek, R. W., and Waters, J. W.: MLS observations of $\mathrm{ClO}$ and $\mathrm{HNO}_{3}$ in the 1996-97 Arctic polar vortex, Geophys. Res. Lett., 24, 2713-2716, 1997.

Santee, M. L., MacKenzie, I. A., Manney, G. L., Chipperfield, M. P., Bernath, P. F., Walker, K. A., Boone, C. D., Froidevaux, L., Livesey, N. J., and Waters, J. W.: A study of stratospheric chlorine partitioning based on new satellite measurements and modeling, J. Geophys. Res., 113, D12307, doi:10.1029/2007JD009057, 2008.

Schlager, H., Arnold, F., Hofmann, D. J., and Deshler, T.: Balloon observations of nitric acid aerosol formation in the Arctic stratosphere: I Gaseous nitric acid, Geophys. Res. Lett., 17, 12751278, doi:10.1029/GL017i004p00433, 1990.

Schraner, M., Rozanov, E., Schnadt Poberaj, C., Kenzelmann, P., Fischer, A. M., Zubov, V., Luo, B. P., Hoyle, C. R., Egorova, T., Fueglistaler, S., Brönnimann, S., Schmutz, W., and Peter, T.: Technical Note: Chemistry-climate model SOCOL: version 2.0 with improved transport and chemistry/microphysics schemes, Atmos. Chem. Phys., 8, 5957-5974, doi:10.5194/acp-8-59572008, 2008.

Shi, Q., Jayne, J. T., Kolb, C. E., Worsnop, D. R., and Davidovits, P.: Kinetic model for reaction of $\mathrm{ClONO}_{2}$ with $\mathrm{H}_{2} \mathrm{O}$ and $\mathrm{HCl}$ and $\mathrm{HOCl}$ with $\mathrm{HCl}$ in sulfuric acid solutions, J. Geophys. Res., 106, 24259-24274, doi:10.1029/2000JD000181, 2001.

Shindell, D. T. and de Zafra, R. L.: Limits on heterogeneous processing in the Antarctic spring vortex from a comparison of measured and modeled chlorine, J. Geophys. Res., 102, 1441-1449, 1997.

Solomon, S.: Stratospheric ozone depletion: A review of concepts and history, Rev. Geophys., 37, 275-316, doi:10.1029/1999RG900008, 1999.

Solomon, S., Garcia, R. R., Rowland, F. S., and Wuebbles, D. J.: On the depletion of Antarctic ozone, Nature, 321, 755-758, 1986.

Solomon, S., Portmann, R. W., Sasaki, T., Hofmann, D. J., and Thompson, D. W. J.: Four decades of ozonesonde measurements over Antarctica, J. Geophys. Res., 110, D21311,
doi:10.1029/2005JD005917, 2005.

Stimpfle, R. M., Wilmouth, D. M., Salawitch, R. J., and Anderson, J. G.: First measurements of $\mathrm{ClOOCl}$ in the stratosphere: The coupling of $\mathrm{ClOOCl}$ and $\mathrm{ClO}$ in the Arctic polar vortex, J. Geophys. Res., 109, D03301, doi:10.1029/2003JD003811, 2004.

Stolarski, R. S., Krueger, A. J., Schoeberl, M. R., McPeters, R. D., Newman, P. A., and Alpert, J. C.: Nimbus 7 satellite measurements of the springtime Antarctic ozone decrease, Nature, 322, 808-811, 1986.

Sumińska-Ebersoldt, O., Lehmann, R., Wegner, T., Grooß, J.-U., Hösen, E., Weigel, R., Frey, W., Griessbach, S., Mitev, V., Emde, C., Volk, C. M., Borrmann, S., Rex, M., Stroh, F., and von Hobe, $\mathrm{M}$.: $\mathrm{ClOOCl}$ photolysis at high solar zenith angles: analysis of the RECONCILE self-match flight, Atmos. Chem. Phys., 12, 1353-1365, doi:10.5194/acp-12-1353-2012, 2012.

Tabazadeh, A., Drdla, K., Schoeberl, M. R., Hamill, P., and Toon, O. B.: Arctic "ozone hole" in a cold volcanic stratosphere, P. Natl. Acad. Sci., 99, 2609-2612, 2002.

Tilmes, S., Müller, R., Grooß, J.-U., and Russell III, J. M.: Ozone loss and chlorine activation in the Arctic winters 1991-2003 derived with the tracer-tracer correlations, Atmos. Chem. Phys., 4, 2181-2213, doi:10.5194/acp-4-2181-2004, 2004.

Tilmes, S., Kinnison, D., Müller, R., Sassi, F., Marsh, D., Boville, B., and Garcia, R.: Evaluation of heterogeneous processes in the polar lower stratosphere in the Whole Atmosphere Community Climate Model, J. Geophys. Res., 112, D24301, doi:10.1029/2006JD008334, 2007.

Tilmes, S., Müller, R., and Salawitch, R. J.: The sensitivity of polar ozone depletion to proposed geoengineering schemes, Science, 320, 1201-1204, doi:10.1126/science.1153966, 2008 a.

Tilmes, S., Müller, R., Salawitch, R. J., Schmidt, U., Webster, C. R., Oelhaf, H., Camy-Peyret, C. C., and Russell III, J. M.: Chemical ozone loss in the Arctic winter 1991-1992, Atmos. Chem. Phys., 8, 1897-1910, doi:10.5194/acp-8-1897-2008, 2008b.

Tilmes, S., Garcia, R. R., Kinnison, D. E., Gettelman, A., and Rasch, P. J.: Impact of geoengineered aerosols on the troposphere and stratosphere, J. Geophys. Res., 114, D12305, doi:10.1029/2008JD011420, 2009.

Tolbert, M. A., Rossi, M. J., and Golden, D. M.: Heterogeneous Interactions of Chlorine Nitrate, Hydrogen Chloride, and Nitric Acid with Sulfuric Acid Surfaces at Stratospheric Temperatures, Geophys. Res. Lett., 15, 847-850, 1988.

Toohey, D. W., Avallone, L. M., Lait, L. R., Newman, P. A., Schoeberl, M. R., Fahey, D. W., Woodbrige, E. L., and Anderson, J. G.: The seasonal evolution of reactive chlorine in the northern hemisphere stratosphere, Science, 261, 1134-1136, 1993.

Toon, G. C., Blavier, J.-F., Sen, B., Margitan, J. J., Webster, C. R., May, R. D., Fahey, D., Gao, R., Del Negro, L., Proffitt, M., Elkins, J. W., Romashkin, P. A., Hurst, D. F., Oltmans, S., Atlas, E., Schauffler, S., Flocke, F., Bui, T. P., Stimpfle, R. M., Bonne, G. P., Voss, P. B., and Cohen, R. C.: Comparison of MkIV balloon and ER-2 aircraft measurements of atmospheric trace gases, J. Geophys. Res., 104, 26779-26790, 1999.

Toon, O. B., Browell, E., Gary, B., Lait, L., Livingston, J., Newman, P., Pueschel, R., Russell, P., Schoeberl, M., Toon, G., Traub, W., Valero, F. P. J., Selkirk, H., and Jordan, J.: Heterogeneous reaction probabilities, solubilities, and the physical state of cold volcanic aerosols, Science, 261, 1136-1140, 1993. 
Turco, R. P. and Hamill, P.: Supercooled sulfuric acid droplets: Perturbed stratospheric chemistry in early winter, Ber. Bunsenges. Phys. Chem., 96, 323-334, 1992.

Vogel, B., Müller, R., Deshler, T., Grooß, J.-U., Karhu, J., McKenna, D. S., Müller, M., Toohey, D., Toon, G. C., and Stroh, F.: Vertical profiles of activated $\mathrm{ClO}$ and ozone loss in the Arctic vortex in January and March 2000: In situ observations and model simulations, J. Geophys. Res., 108, 8334, doi:10.1029/2002JD002564, 2003.

Vogel, B., Feck, T., and Grooß, J.-U.: Impact of stratospheric water vapor enhancements caused by $\mathrm{CH}_{4}$ and $\mathrm{H}_{2}$ increase on polar ozone loss, J. Geophys. Res., 116, D05301, doi:10.1029/2010JD014234, 2011.

Voigt, C., Schlager, H., Luo, B. P., Dörnbrack, A., Roiger, A., Stock, P., Curtius, J., Vössing, H., Borrmann, S., Davies, S., Konopka, P., Schiller, C., Shur, G., and Peter, T.: Nitric Acid Trihydrate (NAT) formation at low NAT supersaturation in Polar Stratospheric Clouds (PSCs), Atmos. Chem. Phys., 5, 13711380, doi:10.5194/acp-5-1371-2005, 2005.

Wagner, R., Möhler, O., Saathoff, H., Stetzer, O., and Schurath, U.: Infrared spectrum of Nitric Acid Dihydrate: Influence of particle shape, J. Phys. Chem. A, 109, 2572-2581, 2005.

Webster, C. R., May, R., Toohey, D., Avallone, L., Anderson, J., Newman, P., Lait, L., Schoeberl, M., Elkins, J., and Chan, K.: Hydrochloric acid loss and chlorine chemistry on polar stratospheric cloud particles in the Arctic winter, Science, 261, 11301134, 1993.

Wegner, T., Grooß, J.-U., von Hobe, M., Stroh, F., SumińskaEbersoldt, O., Mitev, V., Volk, C. M., Hösen, E., Shur, E., and Müller, R.: Chlorine activation on stratospheric aerosols: Uncertainties in parameterizations and surface area, Atmos. Chem. Phys., submitted, 2012.
Wilmouth, D. M., Stimpfle, R. M., Anderson, J. G., Elkins, J. W., Hurst, D. F., Salawitch, R. J., and Lait, L. R.: Evolution of inorganic chlorine partitioning in the Arctic polar vortex, J. Geophys. Res., 111, D16308, doi:10.1029/2005JD006951, 2006.

WMO: Scientific assessment of ozone depletion: 1998, Global Ozone Research and Monitoring Project-Report No. 44, Geneva, Switzerland, 1999.

WMO: Scientific assessment of ozone depletion: 2006, Global Ozone Research and Monitoring Project-Report No. 50, Geneva, Switzerland, 2007.

WMO: Scientific assessment of ozone depletion: 2010, Global Ozone Research and Monitoring Project-Report No. 52, Geneva, Switzerland, 2011.

Wolff, E. W. and Mulvaney, R.: Reactions on sulphuric acid aerosol and on polar stratospheric clouds in the Antarctic stratosphere, Geophys. Res. Lett., 18, 1007-1010, 1991.

Worsnop, D. R., Fox, L. E., Zahniser, M. S., and Wofsy, S. C.: Vapor pressures of solid hydrates of nitric acid: implications for polar stratospheric clouds, Science, 259, 71-74, 1993.

Woyke, T., Müller, R., Stroh, F., McKenna, D. S., Engel, A., Margitan, J. J., Rex, M., and Carslaw, K. S.: A test of our understanding of the ozone chemistry in the Arctic polar vortex based on insitu measurements of $\mathrm{ClO}, \mathrm{BrO}$, and $\mathrm{O}_{3}$ in the 1994/95 winter, J. Geophys. Res., 104, 18755-18768, 1999. 